\title{
A INCONSTITUCIONALIDADE DA PUBLICIDADE RESTRITA DOS PROCESSOS NO TRIBUNAL DE CONTAS DA UNIÃO
}

\author{
JOSÉ PAULO GUEDES BRITO ${ }^{1}$ \\ LINARA OEIRAS ASSUNÇÃO ${ }^{2}$
}

RESUMO: A presente pesquisa examina o regime de publicidade restrita empregado nos processos de contas do Tribunal de Contas da União (TCU) e questiona sua constitucionalidade ante o princípio da publicidade, que figura como preceito geral, havendo o sigilo como exceção. A investigação tem caráter qualitativo e pauta-se em pesquisa bibliográfica direta e indireta, e visa compreender o regime de publicidade especial sob o prisma constitucional. À luz da teoria dos direitos fundamentais de Robert Alexy, e sob a ótica da accountability, conclui-se que a restrição da publicidade carece de validade, pois extrapola as limitações permitidas pelo texto constitucional. Os resultados apontam que o art. 163 do Regimento Interno do TCU (Resolução $\mathrm{n}^{\mathrm{o}}$ 155/2002), o qual limita a publicidade dos processos de contas, é inválido.

Palavras-Chave: Publicidade; Direitos fundamentais; Accountability; Controle externo.

\footnotetext{
${ }^{1}$ Advogado. Técnico de Controle Externo do Tribunal de Contas do Estado do Amapá. Especialista em Perícia e Auditoria Ambiental pelo Centro Universitário Internacional. E-mail: brito.pauloguedes@gmail.com.

2 Doutora em Direito pela UFMG. Professora Adjunta no Curso de Direito da Universidade Federal do Amapá.
} 


\title{
THE UNCONSTITUTIONALITY OF RESTRICTED PUBLICITY OF PROCEEDINGS IN THE UNION'S COURT OF ACCOUNTS
}

\begin{abstract}
The present study examines the restricted advertising regime used in the accounts processes of the Federal Audit Court (TCU) and questions its constitutionality in relation to the principle of publicity, which is a general precept, with secrecy as an exception. The research has a qualitative character and is based on direct and indirect bibliographical research, and aims to understand the regime of special publicity under the constitutional prism. In the light of Robert Alexy's theory of fundamental rights, and from the standpoint of accountability, it is concluded that the restriction of publicity lacks validity, as it goes beyond the limitations allowed by the constitutional text. The results show that art. 163 of the Internal Rules (Resolution No. 155/2002), which limits the advertising of accounts processes, is invalid.
\end{abstract}

KEYWORDS: Advertising; Fundamental rights; Accountability; External Control. 


\section{A INCONSTITUCIONALIDADE DA PUBLICIDADE RESTRITA DOS PROCESSOS NO TRIBUNAL DE CONTAS DA UNIÃO}

\section{INTRODUÇÃO}

O Tribunal de Contas da União (TCU), órgão auxiliar do Congresso Nacional no controle externo da administração pública federal, possui competência para julgar as contas de qualquer pessoa que utilize, arrecade, guarde, gerencie ou administre dinheiros, bens e valores públicos ou pelos quais a União responda, assim como daquelas que de qualquer modo provoquem dano ao erário (CRFB/88, art. 71, II), e poderes para apurar fatos e definir responsabilidades, e suas decisões em que resulte imputação de débito ou multa constituem-se em título executivo (CRFB/88, art. $71, \S 3^{\circ}$ ).

Suas decisões, de natureza administrativa, perpassam por um processo vinculado ao modelo constitucional, devendo obediência ao contraditório e à ampla defesa, conforme já se pronunciou o Supremo Tribunal Federal (STF) por meio da súmula vinculante $\mathrm{n}^{\mathrm{o}} 3$.

No entanto, em que pese o amarrilho constitucional, referido tribunal adota modelo de publicidade especial, previsto no art. 163 do seu Regimento Interno (Resolução no ${ }^{\mathbf{0}}$ 246/2011 - RITCU), o qual veda a publicidade dos atos processuais e condiciona o acesso dos autos às partes e aos procuradores a pedido formulado ao relator, com possibilidade de indeferimento das vistas.

Por conseguinte, pontuamos a problematização do presente artigo justamente na constitucionalidade dessa restrição, a saber: os processos de contas podem ter a publicidade mitigada, com vedação de acesso ao público externo e com possibilidade de vedação também aos próprios responsáveis sob julgamento? Em outras palavras: o modelo de publicidade restrita adotado pelo TCU no âmbito dos processos de contas possui legitimidade democrática e amparo constitucional?

A pesquisa se debruça sobre os processos de contas (meios processuais pelos quais os tribunais de contas realizam a sua função judicante), não se confundindo com os procedimentos de fiscalização (instrumentos pelos quais os tribunais operacionalizam sua função de fiscalização e controle, meios de investigação e apuração). Assim, o problema se recorta exclusivamente sobre a fase processual, momento em que vigoram os institutos correlatos ao devido processo constitucional.

A abordagem da pesquisa é qualitativa, visando um aprofundamento do debate acerca do princípio da publicidade, com aplicação do conceito de legitimidade à jurisdição das Cortes de Contas. Como enfoque, o estudo é crítico dialético (TEIXEIRA, 2005), pois situa o problema na totalidade do sistema normativo nacional e questiona a atuação do TCU frente aos fundamentos democráticos firmados pela Constituição 


\section{REVISTA ESTUDOS INSTITUCIONAIS}

Federal. Para tanto, utilizamos pesquisa bibliográfica e documental, com exame de julgamentos e dados ofertados pela ouvidoria do Tribunal.

Para atingimento dos objetivos, realizamos revisão teórica do princípio democrático e da legitimidade da jurisdição, interpretando as normas da Corte de Contas da União à luz da Constituição Federal de 1988 e da teoria dos direitos fundamentais formulada por Robert Alexy. Devido a desdobramentos da questão, com análise de um cenário alternativo, investigamos os fundamentos do TCU para a manutenção de uma publicidade especial.

A interpretação das disposições regimentais do TCU face aos dispositivos constitucionais considerará em parte a teoria da argumentação jurídica de Alexy (2001), cuja visão procedimentalista póspositivista permitirá a consideração do direito positivado encharcado nos valores democráticos. Assim, vincularemos nossa interpretação à perspectiva semântico-genética ${ }^{3}$, pois as normas relativas à publicidade preceituadas na Constituição revelam uma constitucionalização do processo e a concepção de um processo justo e transparente. Outrossim, identificamos mais uma limitação do objeto decorrente da metodologia: trataremos do preceito geral de publicidade nos processos de contas, não assumindo análise dos casos difíceis, o que explica a dispensa da tese do caso especial ${ }^{4}$. Isso porque, no exame nos casos fáceis bastarão os critérios tradicionais de hermenêutica, tais como: hierarquia, especialidade, temporalidade, etc., complementando-os, quando for necessário, com as regras de argumentação propostas por Alexy: 1) saturação; 2) diferenciação das funções das formas argumentativas; e 3) ordem hierárquica das formas de argumentação ${ }^{5}$. Apenas a título de ilustração mencionaremos a solução da colisão dos princípios mediante a lei de

3 O argumento semântico dirige-se ao conteúdo significativo extraído das palavras da lei, indo buscar os referentes a que estas últimas aludem; a argumentação genética justifica determinada interpretação (semântica) demonstrando sua correspondência à vontade do legislador (LISBOA, 2016, p. 886).

${ }^{4}$ Cf. Alexy (2001, p. 319), "[...] o discurso jurídico é um caso especial do discurso prático" e se fundamenta no fato de que "(1) as discussões jurídicas se preocupam com as questões práticas, isto é, com o que deve ser feito ou deixado de fazer e (2) estas questões são discutidas com a exigência da correção. É questão de 'caso especial', porque as discussões jurídicas (3) acontecem sob limite das situações descritas" (ALEXY, 2001, p. 212).

5 A (1) saturação diz respeito à exigência de esgotamento das razões, de forma que o máximo de razões sejam justificadas; a (2) diferenciação das funções das formas argumentativas refere-se ao reconhecimento dos diferentes resultados a que podem conduzir os argumentos anteriores (semântico, genético, etc.), o que implicará o estabelecimento de (3) critérios que estruturem uma ordem hierárquica das formas de argumentação (LISBOA, 2016, p. 887). 


\section{A INCONSTITUCIONALIDADE DA PUBLICIDADE RESTRITA DOS PROCESSOS NO TRIBUNAL DE CONTAS DA UNIÃO}

colisão e o uso da ponderação, pois para a definição do preceito geral de publicidade segundo o modelo constitucional, conforme dissemos, consideramos apenas os casos fáceis. Consequentemente, não negaremos a possibilidade de restrição da publicidade em seletas hipóteses, o que se perfaz perfeitamente com a escolha do aporte teórico selecionado.

\section{A PUBLICIDADE COMO REQUISITO ESSENCIAL PARA A LEGITIMIDADE DEMOCRÁTICA DO PROCESSO}

Nossas primeiras notas referem-se ao princípio democrático e o exame da legitimidade da jurisdição. Para Norberto Bobbio (1986) a democracia é o exercício do poder público em público, o poder que não se dá com o segredo, pois, ao fundamentar-se no poder emanado do povo, deve se manifestar de forma visível, evidente. O Estado Democrático funda-se na racionalidade das ações e em procedimentos coletivamente justificáveis. A queda do jusnaturalismo demarca o fim da justificação metafísica, exigindo-se em seu lugar processos racionais e visíveis. Para Bobbio (1986, p. 117), "a publicidade dos atos do poder [...] representa o verdadeiro momento de reviravolta na transformação do estado moderno que passa de estado absoluto a estado de direito".

Nessa linha, o filósofo italiano lembra-se do Panopticon de Bentham e o seu sistema de controle: a torre onde se encontra o vigilante esconde-o na penumbra enquanto este vê, de modo onividente, todas as ações do vigiado. No entanto, o próprio Bentham problematizou a questão, como fez o Romano Juvenal, indagando-se: "Quis custodiei custodes?" (Quem vigia o vigilante?). Em resposta Bentham apontou para inspeções rotineiras realizadas pelas instituições competentes e pelo público:

Este expediente representa uma fase ulterior da dissociação da dupla "ver-ser visto". O prisioneiro é o não vidente visível, o vigilante é o vidente visível, o povo completa a escala enquanto vidente não visto a não ser por si mesmo e que é, portanto, com respeito aos outros, invisível. O vidente invisível é ainda uma vez o soberano. (BOBBIO, 1986, p. 113).

O sistema de vigias de Bentham é ilustrativo e denota grande significado para a publicidade. $\mathrm{O}$ vigia, mesmo nomeado para a função, sob o lastro formal da legalidade, não dispensa um procedimento de fiscalização que pode ser feito por outro vigia, o qual exigiria fiscalização 


\section{REVISTA ESTUDOS INSTITUCIONAIS}

superior, numa escala infinita. A escala se completa quando atinge o público, o soberano no modelo democrático, único vidente invisível. De modo rudimentar, mas ainda assim de muito significado, transpõe-se o raciocínio para o sistema de democracia representativa no qual os representantes, embora legalmente designados, não dispensam a vigilância do soberano. $\mathrm{O}$ representante, portanto, só poderá atuar legitimamente se estiver visível, cujos atos serão públicos e passíveis de avaliação pelo cidadão.

Para Santos (2008), a democracia que for exercida sem transparência e sem mecanismos de controle dos atos dos representantes do povo não terá legitimidade, e acrescenta:

De fato, é nos Estados totalitários e despóticos que os governantes praticam atos de poder às ocultas, escudados pela sombra do sigilo e salvo de qualquer fiscalização. Na democracia, ao revés, a coisa pública é gerida às claras, aos olhos de quem quiser ver. Daí a explicitação, no art. 37 da Constituição brasileira, de que a Administração Pública obedecerá, além dos princípios da legalidade, da impessoalidade, da moralidade e da eficiência, o da publicidade". (SANTOS, 2008, p. 174).

Nesse sentido, Dinamarco (2001) destaca que no atual estágio da teoria geral do processo se adquiriu a consciência de que o processo precisa refletir as bases do regime democrático, consubstanciando-se em microcosmo da democracia. Na mesma esteira, Almada (2004), referindose à expressão usada por Taruffo, acentua que ao auditório universal (o público em geral) devem ser revelados os atos do processo, a fim de que se possa ter legitimidade na atividade jurisdicional. Passos (1999, p. 56) resumiu a questão identificando a subordinação da jurisdição ao modelo democrático:

[...] também a função jurisdicional se coloca sob o império da lei e sujeita-se à deslegitimação pelos agentes das demais funções básicas do Estado, como mandatários do povo soberano, e pelo próprio povo, diretamente [...]. Não se eximiu nenhum agente da função política da necessidade de sua prévia e adequada legitimação para desempenhá-la, nem do imperativo de ser responsabilizável todo e qualquer agente público, dada a incompatibilidade, num sistema democrático, de 


\title{
A INCONSTITUCIONALIDADE DA PUBLICIDADE RESTRITA DOS PROCESSOS NO TRIBUNAL DE CONTAS DA UNIÃO
}

\author{
outorgar-se poder sem se fazer possível \\ responsabilização do outorgado [...].
}

Mesmo o agente público no exercício da jurisdição submete-se ao controle social e aos olhos públicos. Atuação fora desse ambiente de controle escapa da legitimidade, atentando contra a Constituição.

Por fim, é salutar retornar a Bobbio referindo-se ao uso do computador antes do boom da internet, como ferramenta de controle democrático. O filósofo, atento ao desenvolvimento de novas tecnologias, indagou-se sobre a viabilidade de uma democracia direta, dadas as novas possibilidades do futuro:

[...] hoje a ideia de que a democracia direta se tenha tornado possível pelo uso dos computadores não é mais o fruto de uma imaginação extravagante. E por que o próprio uso dos computadores não poderia tornar possível um conhecimento capilar dos cidadãos de um grande estado por parte de quem detém o poder? (BOBBIO, 1986, p. 119).

As ferramentas digitais permitem a proliferação da informação sem delimitações espaciais, expandindo sobremaneira os limites da democracia direta. Assim, quais os embargos para uma participação mais efetiva do cidadão? Para os tecnocratas, anota Bobbio, o limite da participação do cidadão está na sua capacidade de compreensão da informação. Ocorre que tecnocracia e democracia são antitéticas: a primeira reserva o espaço do poder para alguns poucos, enquanto a segunda, por sua natureza, exige participação do cidadão comum. Nesse sentido, Lefebvre (1969, p. 15) aponta que:

Os homens qualificados de tecnocratas passam por possuir importantes competências, bem como o dom da eficácia. Teriam o quase monopólio dessas duas coisas. Seriam ao mesmo tempo capazes de descobrir soluções técnicas que forneçam uma resposta aos problemas muito preciosos apresentados pela prática e capazes também de impor essas soluções (capazes de comandar).

A remissão à tecnocracia é frequente na defesa de algumas posições institucionais, dentre elas a perspectiva especializada dos processos de 


\section{REVISTA ESTUDOS INSTITUCIONAIS}

contas. Seu perigo reside em afastar do cidadão comum o domínio da coisa pública, remanejando para órgãos especializados não apenas o dever do controle, mas também a sua exclusividade.

\section{A PUBLICIDADE NA CONSTITUIÇÃO FEDERAL DE 1988}

A narrativa hiperbólica de Franz Kafka em "O processo" relata o absurdo de uma acusação nas sombras, na qual o réu, Josef K., desconhece o teor da imputação e não sabe ao certo quem o acusa. Um processo nas sombras é intolerável porque atinge garantia fundamental grafada nas constituições democráticas e nos tratados internacionais de direitos humanos. Proclama a Convenção Europeia de Direitos Humanos, artigo $6^{\circ}$, que "qualquer pessoa tem direito a que a sua causa seja examinada, equitativa e publicamente $[. .]$.$" ", e o Pacto Internacional$ sobre Direitos Civis e Políticos, artigo 14, dispóe que "[...] Toda pessoa terá o direito de ser ouvida publicamente e com devidas garantias por um tribunal competente $[\ldots]^{\prime \prime}$.

Internamente, a Constituição brasileira prevê especialmente em dois momentos a publicidade dos atos processuais:

Art. $5^{\circ}[\ldots]$

LX - a lei só poderá restringir a publicidade dos atos processuais quando a defesa da intimidade ou o interesse social o exigirem;

Art. 93. [...]

IX - todos os julgamentos dos órgãos do Poder Judiciário serão públicos, e fundamentadas todas as decisões, sob pena de nulidade, podendo a lei limitar a presença, em determinados atos, às próprias partes e a seus advogados, ou somente a estes, em casos nos quais a preservação do direito à intimidade do interessado no sigilo não prejudique o interesse público à informação; (Redação dada pela Emenda Constitucional no ${ }^{-45}$, de 2004).

Já o direito de acesso à informação também é assegurado como direito fundamental pela CRFB/88:

Art. $5^{\mathrm{o}}[\ldots]$

XXXIII - todos têm direito a receber dos órgãos públicos informações de seu interesse particular, ou de interesse 


\section{A INCONSTITUCIONALIDADE DA PUBLICIDADE RESTRITA DOS PROCESSOS NO TRIBUNAL DE CONTAS DA UNIÃO}

coletivo ou geral, que serão prestadas no prazo da lei, sob pena de responsabilidade, ressalvadas aquelas cujo sigilo seja imprescindível à segurança da sociedade e do Estado.

Por fim, o art. 37, caput, preceitua que:

Art. 37. A Administração Pública direta e indireta de qualquer dos Poderes da União, dos Estados, do Distrito Federal e dos Municípios obedecerá aos princípios de legalidade, impessoalidade, moralidade, publicidade e eficiência [...].

§ $3^{\text {o }}$ A lei disciplinará as formas de participação do usuário na administração pública direta e indireta, regulando especialmente: (Redação dada pela Emenda Constitucional $\mathrm{n}^{\mathbf{0}}$ 19, de 1998)

$[\ldots]$

II - o acesso dos usuários a registros administrativos e a informações sobre atos de governo, observado o disposto no art. $5^{\circ}$, X e XXXIII;

Como princípio, a publicidade é uma garantia de segundo grau, isto é, uma garantia posta a serviço de outras garantias (ABDO, 2008). Essa característica instrumental possui duas finalidades bem conhecidas: (1) asseguradora do devido processo legal, correlacionando-se intimamente com o contraditório e a ampla defesa; (2) meio da accountability, mecanismo de transparência do processo, permitindo o controle social, ligando-se umbilicalmente com a motivação da decisão.

Ancorando-se nessa distinção, a doutrina costuma classificar o princípio em publicidade interna - aquela destinada às partes, aos procuradores e aos interessados - e publicidade externa - destinada ao público em geral, sem interesse imediato no julgamento (ABDO, 2008).

É apodítica a relação entre a publicidade interna e os princípios do contraditório e da ampla defesa, isso porque a contra argumentação pressupõe uma informação. Se a parte não for informada terá o contraditório prejudicado, maculando, de forma mediata, o princípio da isonomia. Para alguns autores, como Almada (2004) e Abdo (2008), a publicidade interna não levanta grandes questionamentos porque é situação remansosa no direito. Questão duvidosa seria o acesso à informação constante em processo ou investigação sob sigilo. A discussão ensejou a súmula vinculante $\mathrm{n}^{-} \mathbf{1 4}$, na qual o STF assentou: 


\section{REVISTA ESTUDOS INSTITUCIONAIS}

É direito do defensor, no interesse do representado, ter acesso amplo aos elementos de prova que, já documentados em procedimento investigatório realizado por órgão com competência de polícia judiciária, digam respeito ao exercício do direito de defesa.

Dessa maneira, o campo de debate estaria restrito à publicidade externa, posto que a própria Constituição e os tratados internacionais admitem a sua restrição em caso de interesse público e preservação da intimidade. Todavia, no TCU há previsão regimental para restrição da publicidade mesmo para as partes e procuradores, não sendo pacífica a questão da publicidade interna no âmbito dos seus processos e mais tormentosa ainda é a questão da publicidade externa.

Mais que um princípio, a publicidade está grafada como regra no direito positivo brasileiro. No âmbito do processo civil, o artigo 11 do Novo Código de Processo Civil (NCPC) preceitua que "Todos os julgamentos dos órgãos do Poder Judiciário serão públicos, e fundamentadas todas as decisões, sob pena de nulidade". Nos casos de segredo de justiça pode ser autorizada a presença somente das partes, de seus advogados, de defensores públicos ou do Ministério Público. Já no processo administrativo, a Lei $n^{\mathbf{0}}$ 9.784/99, estabelece no artigo 46 que os interessados podem obter vista e cópia do processo.

Note-se suplementarmente que o NCPC, art. 15, dispõe que suas normas se aplicam subsidiária e supletivamente aos processos administrativos. Ademais, o próprio RITCU, art. 298, admite aplicação de normas processuais de outros ramos do direito, desde que compatíveis com a sua lei orgânica.

O exame dos limites da publicidade configura-se como o cerne da questão, sendo necessário, para tanto, a distinção entre princípio e regra. E o que far-se-á doravante.

\section{SOBRE OS PRINCÍPIOS E REGRAS SEGUNDO A TEORIA DE ROBERT ALEXY}

$\mathrm{Na}$ esteira da teoria dos direitos fundamentais de Robert Alexy, princípios e regras são normas que se distinguem entre si mediante um critério qualitativo. Distinções quantitativas, baseadas na generalidade princípios como normas gerais e regras como normas específicas - são de pouca utilidade porque erodem no primeiro teste, quando se verifica, v.g., 


\section{A INCONSTITUCIONALIDADE DA PUBLICIDADE RESTRITA DOS PROCESSOS NO TRIBUNAL DE CONTAS DA UNIÃO}

regra de caráter genérico confundindo-se com um princípio. Na proposta de Alexy os princípios ordenam que algo se realize na maior medida possível, enquanto regras são mandamentos fechados, que só admitem sim ou não.

Os princípios aplicam-se mediante o balanceamento e o uso da proporcionalidade. É dizer que devem ser aplicados o tanto quanto for possível, variando em decorrência de questões fáticas ou jurídicas. Já as regras aplicam-se por meio da subsunção. Em outras palavras, uma vez válidas e não havendo exceção, serão aplicadas tal como previstas, nem mais, nem menos ${ }^{6}$. Os princípios constituem-se mandamentos de otimização. As regras, como traduz Barroso (1999), são mandamentos de definição. Para Alexy:

O ponto decisivo na distinção entre regras e princípios é que princípios são normas que ordenam que algo seja realizado na maior medida possível dentro das possibilidades jurídicas e fáticas existentes. [...] Já as regras são normas que são sempre ou satisfeitas ou não satisfeitas. Se uma regra vale, então deve se fazer exatamente aquilo que ela exige; nem mais, nem menos. Regras, contém, portanto, determinações no âmbito daquilo que é fática e juridicamente possível. Isso significa que a distinção entre regras e princípios é uma distinção qualitativa, e não uma distinção de grau. (ALEXY, 2017, p. 90-91. Grifos no original).

Conforme destacado por Bustamante (2010, p. 156), "as regras, se racionalmente justificáveis, resultam de uma ponderação de princípios". Isso se confirma com mais vigor pela leitura da lei de colisão: "as condições sobre as quais um princípio tem precedência em face de outro constituem o suporte fático de uma regra que expressa a consequência jurídica do princípio que tem precedência" (ALEXY, 2017, p. 99).

A razão de ser dos princípios está na impossibilidade de se estabelecer um sistema somente de regras. Em algum momento o legislador fixará deveres que não podem ser aplicados por meio da subsunção. Como Alexy adverte (2017, p. 139): “[...] No espaçoso mundo dos princípios há lugar para muita coisa. Esse mundo pode ser chamado de um mundo dever-ser ideal". Por outro lado, "[...] Se a regra não é aplicável

${ }^{6}$ Não trabalha-se aqui com as discussões sobre a possibilidade de superar regras. 


\section{REVISTA ESTUDOS INSTITUCIONAIS}

independentemente de sopesamentos, então, ela é, enquanto regra, incompleta" (2017, p. 140).

\section{Os preceitos da publicidade: regras ou princípios?}

Identificar a natureza dos preceitos constitucionais da publicidade, se regras, se princípios, permitirá averiguar a validade constitucional do regime especial utilizado pelo TCU. Isso porque os princípios constitucionais permitem a restrição pelo legislador:

[...] os princípios constitucionais expressamente admitem a sua restrição pelo legislador infraconstitucional. Embora o legislador possa violar esse princípio se o restringir de forma irracional ou em desconformidade com as exigências processuais estabelecidas pela máxima da proporcionalidade, o princípio democrático estabelece uma presunção de legitimidade para as restrições estabelecidas pelo legislador. (BUSTAMANTE, 2010, p. 171)

Comecemos pelo art. 37. A norma contida no caput é expressa ao dispor a publicidade como princípio. Esse caráter é reforçado pelo inciso II, do $\S 2^{\underline{o}}$, o qual demanda a regulamentação da matéria por meio de ato legiferante infraconstitucional. Em assim fazendo, a Lei de Acesso à Informação (LAI), Lei n⿳ำ 12.527/2011, preceitua:

Art. $3^{\circ}$ Os procedimentos previstos nesta lei destinam-se a assegurar o direito fundamental de acesso à informação e devem ser executados em conformidade com os princípios básicos da administração pública e com as seguintes diretrizes:

I - observância da publicidade como preceito geral e do sigilo como exceção.

$[\ldots]$

Referida lei torna regra o princípio do art. 37, dispondo expressamente que a informação sigilosa será exceção e a define como "aquela submetida temporariamente à restrição de acesso em razão de sua imprescindibilidade para a segurança da sociedade e do Estado" (art. $4^{\text {o }}$, III) e informação pessoal, também protegida, como "aquela relacionada à pessoa natural identificada ou identificável" (art. $4^{\circ}$, IV). No art. 23, a LAI estabelece que as informações relativas à segurança da 


\section{A INCONSTITUCIONALIDADE DA PUBLICIDADE RESTRITA DOS PROCESSOS NO TRIBUNAL DE CONTAS DA UNIÃO}

sociedade e do Estado podem ser restringidas. No geral, a informação estatal nasce pública, mas pode, por meio de ato administrativo fundamentado e motivado, ser classificada como sigilosa (LAI, art. 28). E mais: a recusa de fornecimento de informação pública constitui ato ilícito (art. 32).

$\mathrm{O}$ inciso LX do art. $5^{\mathrm{o}}$ assevera garantia individual, cujo escopo envolve um processo justo, transparente. Geneticamente, a garantia se vincula ao princípio democrático e estipula como cláusula de legitimidade a transparência do processo. $O$ mandamento é de determinação, não aplicável apenas nos casos de exceção, configurando a norma como regra. Aqui a Constituição define expressamente os limites de atuação da lei: a publicidade dos atos processuais - sejam eles administrativos ou judiciais - só será restringida quando a defesa da intimidade ou o interesse social o exigirem. O mandamento é direto, não enseja, prima facie, aplicação proporcional. A própria norma traz em si a sua reserva, cláusulas de exceção: o interesse social e a intimidade. Portanto, o ato processual será público, salvo se incidir uma cláusula de exceção.

É preciso ratificar um ponto importante: somente a lei, derivada do devido procedimento democrático, tem o condão de definir as exceções, nos limites estabelecidos. A dificuldade residiria em estabelecer o conteúdo dos conceitos indeterminados de intimidade e interesse social. Quiçá neste ponto resida o ponto discricionário do legislador, mas sempre condicionado ao intento da constituição: a garantia de um processo justo, transparente, legítimo.

De qualquer sorte, o art. 188 do NCPC estatui que os atos processuais são públicos, mas tramitam em segredo de justiça os processos em que se exija o interesse público ou social, que versem sobre direito de família, os que constem dados protegidos pelo direito à intimidade e os que versem sobre arbitragem nos termos da lei. A norma processual civil mantém as definições constitucionais e normatiza como preceito geral a publicidade e enumera as respectivas exceções (e não podemos olvidar do art. 11, citado acima). Por consequência, não serão públicos apenas os atos acobertados pelo manto das excepcionalidades expressamente estipuladas.

A regra do direito adjetivo civil tem respaldo em norma superior, a qual também julgamos como regra, vez que preceitua, de modo peremptório, que "todos os julgamentos dos órgãos do Poder Judiciário serão públicos". Trata-se do art. 93, IX, o qual mais uma vez enumera as cláusulas de exceção: a intimidade ou interesse público. A semântica da norma espelha uma decisão do legislador constituinte: os processos serão 


\section{REVISTA ESTUDOS INSTITUCIONAIS}

públicos, salvo casos de exceções permitidos pela própria constituição. A norma fixa, determina, vincula a publicidade como preceito geral. E o faz com o intento de garantir a accountability dos julgamentos, tornando possível o contraditório e o controle social, vez que no mesmo dispositivo determina a motivação das decisões.

Por fim, o inciso XXXIII, do art. 5ํㅡ, registra na Constituição outro direito fundamental associado à informação, ressalvando apenas aquelas que digam respeito à segurança da sociedade e do Estado. Tolher a informação neste caso, conforme o preceito constitucional dispõe, enseja a responsabilização do agente. Entendemos que esse dispositivo também se configura como regra, ressalvando novamente o interesse social dessa vez qualificando tal interesse com maior carga, relacionando-o com a proteção da segurança da socied ade e do estado - e apresenta norma de eficácia limitada apenas o prazo a ser estabelecido em lei. A LAI, ao disciplinar a matéria, definiu que a entrega da informação dever ser imediata e, não sendo possível, no prazo de vinte dias, prorrogável somente por mais dez, mediante justificativa expressa (art. 11).

Todas essas regras, cujo mandamento pode ser reduzido à máxima: os atos processuais são públicos, salvo as excepcionalidades legalmente previstas, amparam-se no princípio da publicidade processual e na legitimidade da atuação dos agentes públicos, sejam eles administradores, juízes ou ministros do TCU. Esses princípios normatizam valores inerentes a um Estado Democrático de Direito e não poderia ser diferente. Reconhecer esses princípios e esses valores grafados na Constituição permite conhecer das opções do legislador Constituinte. Para Bustamante (2010, p. 156-157):

A legislação tem uma importância central no sistema de Alexy porque ela universaliza a solução para a colisão de princípios e estabelece uma prioridade das decisões democráticas do legislador em todas as situações de obscuridade no texto constitucional.

Frisemos: tais normas - princípios e regras - cuidam de atos processuais, não se confundem com atos ou procedimentos de investigação, seja de inquérito policial, seja de fiscalização dos Tribunais de Contas. A publicidade desses atos é opção do legislador constituinte, condizente com o modelo democrático de Estado.

Passemos agora ao estudo dos conflitos normativos, a fim de desenhar o quadro teórico que nos permita examinar a validade da regra estabelecida pelo regimento interno do TCU. 


\section{A INCONSTITUCIONALIDADE DA PUBLICIDADE RESTRITA DOS PROCESSOS NO TRIBUNAL DE CONTAS DA UNIÃO}

\section{Conflitos normativos}

A distinção entre regras e princípios tem grandes implicações na solução de conflitos normativos. O conflito entre regras se resolve basicamente de duas formas: ou se tem uma cláusula de exceção, quando uma norma específica excepciona norma geral, ou se realiza um juízo de validade. Se não for possível incluir a cláusula de exceção, uma das normas necessariamente será declarada inválida.

Respeitante à colisão dos princípios a solução é totalmente diversa. Se um princípio cede perante o outro, não será declarado inválido. $\mathrm{Na}$ verdade, a solução se dá porque um dos princípios tem precedência sobre o outro em face de determinadas condições, concretamente verificáveis. Segundo Alexy, conflitos entre regras ocorrem na dimensão da validade, enquanto as colisões entre princípios ocorrem na dimensão do peso.

Em nenhuma hipótese um princípio afastado mediante um juízo de ponderação será declarado inválido, eliminado abstratamente. O exame dos princípios perpassa por uma relação de precedência condicionada. Assim define a lei de colisão: a relação $P 1$ - $P 2$ deve ser mediada por uma condição $(P 1-P 2) C$. Dizer que a colisão entre princípios se dá na dimensão do peso é reconhecer que em determinada situação real o princípio P1 cede em relação a P2 porque naquele caso em específico P1 tinha menor importância que $\mathrm{P} 2$, ou seja, peso. Os princípios, diferentemente das regras, sempre são válidos. O que pode ocorrer é que um princípio não pertença a determinado sistema jurídico, o que neste caso afasta o sopesamento, pois sequer há colisão. É conhecida a solução racional elaborada pelo insigne filósofo alemão, a qual atribui um exame trifásico da proporcionalidade na compararão entre os pesos dos princípios, a saber: a adequação, necessidade e proporcionalidade em sentido estrito, de forma que a ausência de uma implica na pronta desconsideração das seguintes (LISBOA, 2016). Apenas nos referimos à solução, haja vista que o presente artigo se debruça sobre os casos fáceis.

O enfrentamento entre princípios se resolve por meio da lei de colisão, da qual se extrai uma regra, aplicável por subsunção. Porém, há complexidades maiores. Bustamante (2010) identifica quatro possibilidades de conflitos normativos no mesmo nível hierárquico: 1 . conflito (em sentido estrito) 7 entre um princípio e uma regra; 2 . colisão

\footnotetext{
${ }^{7}$ Há duas espécies de conflitos normativos em sentido amplo: os conflitos em sentido estrito e as colisões. Um conflito em sentido estrito entre normas jurídicas se dá quando não é possível admitir a validade simultânea das normas conflitantes no mesmo tempo e no mesmo lugar. Podem ocorrer conflitos em sentido estrito envolvendo tanto regras quanto princípios jurídicos. Conflitos normativos em sentido estrito ocorrem na
} 


\section{REVISTA ESTUDOS INSTITUCIONAIS}

entre um princípio e um outro princípio; 3. conflito (em sentido estrito) entre duas regras 4; conflito (em sentido estrito) entre dois princípios. Entre normas de níveis hierárquicos distintos, o professor apresenta seis hipóteses: (i) conflito (em sentido estrito) entre uma regra constitucional e uma regra infraconstitucional; (ii) colisão entre uma regra constitucional e um princípio infraconstitucional; (iii) conflito (em sentido estrito) entre um princípio constitucional e um princípio infraconstitucional; (iv) colisão entre um princípio constitucional e um princípio infraconstitucional; (v) conflito (em sentido estrito) entre um princípio constitucional e uma regra infraconstitucional; (vi) colisão entre um princípio constitucional e uma regra infraconstitucional.

Dados os objetivos deste trabalho, interessa-nos os conflitos do segundo tipo, entre normas de hierarquia diversa. Considerando o modelo estatuído pelo TCU, com regra regimental, importa o exame de duas possibilidades: 1. conflito (em sentido estrito) entre uma regra constitucional e uma regra infraconstitucional; 2. conflito (em sentido estrito) entre um princípio constitucional e uma regra infraconstitucional.

Para Bustamante, o caso 1 denota conflito no campo da validade da norma jurídica e é resolvido de forma relativamente óbvia: aplica-se o critério hierárquico e invalida-se por completo a norma infraconstitucional. Isso porque no conflito entre duas regras de nível hierárquico diferentes, cede, como inválida, a de menor status. Nessa hipótese os critérios tradicionais da hermenêutica, em especial o da hierarquia, resolvem a questão com tranquilidade.

O caso 2 também transcorre no campo da validade, mas apresenta maiores dificuldades. Embora de nível hierárquico superior, o princípio, como mandamento de otimização, permite a sua redução pelo legislador infraconstitucional, pois mesmo não sendo aplicado, continua sendo válido. Segundo Bustamante (2010, p. 171-172):

Quem quer que argumente pela inconstitucionalidade de uma restrição a um princípio constitucional deve demonstrar que o legislador, ao ponderar esse princípio com o princípio que justifica a regra restritiva, extrapolou os limites da margem de apreciação que lhe fora deixada pelo constituinte.

dimensão da validade e só podem ser resolvidos pela invalidação de uma das normas conflitantes. Uma colisão, por outro lado, é o tipo de conflito em sentido amplo que é resolvido na dimensão da aplicabilidade, e não mais da validade, das normas jurídicas conflitantes (BUSTAMANTE, 2010, p. 167). 


\section{A INCONSTITUCIONALIDADE DA PUBLICIDADE RESTRITA DOS PROCESSOS NO TRIBUNAL DE CONTAS DA UNIÃO}

O legislador infraconstitucional, apoiado no princípio democrático, edita norma com presunção de constitucionalidade, cabendo um ônus maior de argumentação para aquele que alegar ofensa a princípio constitucional. Em nosso entender não é o caso do regime de publicidade restrita do TCU, carente da presunção de constitucionalidade, vez que se ampara em norma de status infralegal, não possuindo o lastro do princípio democrático.

Destarte, no caso 5 deverá ocorrer a ponderação entre o princípio que foi agredido e o princípio que fundamenta a regra, sendo possível três resultados:

i) a restrição está conclusivamente determinada pela
Constituição no caso concreto, ou seja, é possível inferir
diretamente da constituição a conclusão de que o
princípio P1 deve ser restringido com fundamento em
P2; (ii) a restrição está conclusivamente proibida pela
Constituição, ou seja, ao se ponderar P1 e P2 se chega
com segurança à conclusão de que o princípio
restringido tem peso superior ao princípio que justifica
sua restrição; (iii) a restriçãa não está nem
conclusivamente proibida nem conclusivamente
permitida pelas normas de direito fundamental
diretamente instituídas pela Constituição.
(BUSTAMANTE, 2010, p. 172).

Na hipótese (i) a regra é válida, pois atua dentro das possibilidades de aplicação da Constituição. Na situação (ii) a regra é inválida, porque a Constituição não permite a disposição em contrário. No cenário (iii) a regra será válida independentemente da posição adotada, uma vez que, se a Constituição não veda, pode o legislador, pelo princípio a legalidade, regular a questão. Porém, neste caso, a mesma legalidade veda atuação de norma infralegal.

\section{CONSIDERAÇÕES SOBRE OS PROCESSOS DE CONTAS E DISTINÇÃO DOS PROCEDIMENTOS DE FISCALIZAÇÃO}

A Instrução Normativa TCU no 63/2010 (IN TCU 63/2010) define o processo de contas como "processo de trabalho do controle externo destinado a avaliar e julgar o desempenho e a conformidade da gestão das pessoas abrangidas pelos incisos I, III, IV, V e VI do art. $5^{\circ}$ da Lei $n^{0}$ $8.443 / 92[\ldots]^{\prime \prime}$. Os incisos remetidos à lei orgânica do TCU definem as 


\section{REVISTA ESTUDOS INSTITUCIONAIS}

pessoas sujeitas à jurisdição do órgão e se submetem ao dever de prestar contas $^{8}$. A mesma instrução define ainda duas espécies do gênero: Processo de contas ordinárias: "processo de contas referente a exercício financeiro determinado, constituído pelo Tribunal segundo critérios de risco, materialidade e relevância" e Processo de contas extraordinárias: "processo de contas constituído por ocasião da extinção, liquidação, dissolução, transformação, fusão, incorporação ou desestatização de unidades jurisdicionadas [...]".

Existe ainda um outro tipo de processo de contas, destinado a julgar os responsáveis abrangidos pelo inciso II, do art. 50 da Lei $\mathrm{n}^{\mathrm{o}}$ 8.443/92 (aqueles que derem causa a perda, extravio ou outra irregularidade de que resulte dano ao Erário), a saber, a Tomada de contas especial. Segundo a Instrução Normativa TCU no 71/2012 (IN TCU nº 71/2012):

Tomada de contas especial é um processo administrativo devidamente formalizado, com rito próprio, para apurar responsabilidade por ocorrência de dano à administração pública federal, com apuração de fatos, quantificação do dano, identificação dos responsáveis e obter o respectivo ressarcimento.

Reunindo os preceitos das duas instruções é possível estabelecer que os processos de contas possuem espécies ordinárias, extraordinárias e especiais. As duas primeiras cuidam de contas anuais, quando o responsável possui o dever de prestar as contas. Assim, o tipo processual

8 "Art. $5^{\circ}$ A jurisdição do Tribunal abrange:

I - qualquer pessoa física, órgão ou entidade a que se refere o inciso I do art. $1^{\circ}$ desta Lei, que utilize, arrecade, guarde, gerencie ou administre dinheiros, bens e valores públicos ou pelos quais a União responda, ou que, em nome desta, assuma obrigações de natureza pecuniária;

II - aqueles que derem causa a perda, extravio ou outra irregularidade de que resulte dano ao Erário;

III - os dirigentes ou liquidantes das empresas encampadas ou sob intervenção ou que de qualquer modo venham a integrar, provisória ou permanentemente, o patrimônio da União ou de outra entidade pública federal;

IV - os responsáveis pelas contas nacionais das empresas supranacionais de cujo capital social a União participe, de forma direta ou indireta, nos termos do tratado constitutivo.

$\mathrm{V}$ - os responsáveis por entidades dotadas de personalidade jurídica de direito privado que recebam contribuiçõos parafiscais e prestem serviço de interesse público ou social;

VI - todos aqueles que lhe devam prestar contas ou cujos atos estejam sujeitos à sua fiscalização por expressa disposição de Lei." 


\section{A INCONSTITUCIONALIDADE DA PUBLICIDADE RESTRITA DOS PROCESSOS NO TRIBUNAL DE CONTAS DA UNIÃO}

mais comum é o de Prestação de contas. Destaca-se que, na omissão do responsável, instaura-se a Tomada de contas.

A Tomada de contas especial se destina a apuração de fatos específicos, com intuito de quantificar eventual dano e identificar possíveis responsáveis. Enquanto os processos de contas anuais referemse a dever normativo, configurando-se como meios aptos ao julgamento e avaliação da gestão (aferindo-se a conformidade e o desempenho), a tomada de contas especial tem como objetivo maior resguardar o erário, tanto que sua instauração é dispensável caso haja outro meio mais eficaz para a restituição do dano (IN 71/2012, art. 3oㅡ). Em resumo: prestações e tomadas de contas atingem pessoa vinculada à administração pública federal. A tomada de contas especial alcança qualquer pessoa que tenha causado dano ao erário, mesmo que não tenha relação formal com a administração. Nessa linha, Lima (2015, 1. 664) estabelece ainda as seguintes diferenças entre os citados meios processuais:

Em primeiro lugar, cada órgão ou entidade só constitui um processo anual de TC [Tomada de Contas] ou PC [Prestação de Contas]. Não há, entretanto, limite ao número de TCEs [Tomada de Contas Especiais] que poderão ser instaladas no mesmo exercício em cada órgão ou entidade. Sempre que se verificarem as hipóteses de instauração de TCE, esta deverá ser realizada, independentemente de encontrarem-se em curso uma ou mais TCEs no mesmo órgão ou entidade, desde que os fatos geradores não sejam os mesmos.

O rol dos responsáveis nos processos de TCs e de PCs é composto de indivíduos vinculados à administração pública federal, como dirigentes, membros de conselhos de administração e fiscais etc. Nas TCEs, os responsáveis podem ser qualquer pessoa física ou jurídica, pública ou privada, às quais possa ser imputada a obrigação de ressarcir o Erário. Assim, é comum observar em TCEs que o responsável é um Prefeito, um Secretário de Estado, um bolsista de doutorado, uma organização do Terceiro Setor ou uma empresa privada.

Por sua vez, os instrumentos de fiscalização são cinco, de acordo com o regimento interno do TCU (arts. 238 a 243), quais sejam: levantamento, auditoria, inspeção, acompanhamento e monitoramento. Auditoria e 


\section{REVISTA ESTUDOS INSTITUCIONAIS}

inspeção são instrumentos com menção constitucional (art. 71, IV). Todos eles caracterizam-se como procedimentos de controle e materializam a função fiscalizadora do tribunal, como podemos depreender do art. 249 do RITCU: "Para assegurar a eficácia do controle e para instruir o julgamento das contas, o Tribunal efetuará a fiscalização dos atos de que resulte receita ou despesa, praticados pelos responsáveis sujeitos à sua jurisdição $[\ldots]^{\prime \prime}$.

Assim, não há como julgar, em sentido estrito, um relatório de auditoria, muito menos imputar responsabilidades ou débitos. Eventualmente, surgindo fato que enseje dano, a ação fiscalizatória deve ser convertida em tomada de contas especial (Lei no 8.443/93, art. 47 e RITCU, art. 252) ${ }^{9}$.

Quadro 1 - caracterização dos instrumentos

\section{INSTRUMENTO}

Levantamento

Auditoria

Inspeção

Acompanhamento

Monitoramento

\section{CARACTERÍSTICA}

\begin{tabular}{|c|}
\hline $\begin{array}{c}\text { Destina-se a acumular conhecimento sobre o } \\
\text { órgão ou empreendimento } \\
\text { Procedimento de maior profundidade e } \\
\text { dimensão }\end{array}$ \\
\hline Medida adotada no curso de um processo \\
\hline $\begin{array}{c}\text { Não exige a presença in loco da equipe de } \\
\text { fiscalização }\end{array}$ \\
\hline É consequência de uma deliberação do Tribunal \\
\hline
\end{tabular}
Fonte: Lima (2015, p. 777) adaptado.

Os instrumentos de fiscalização são denominados frequentemente de processos de fiscalização, sendo possível, todavia, tão somente a imputação de algumas penalidades, como a multa prevista no inciso III, do art. 58 da Lei Orgânica do TCU. Para tanto, faz-se necessário a abertura de contraditório por meio de audiência (art. 43, parágrafo único). Observe-se que neste caso o termo "processo" assume acepção ampla, não se confundindo com o meio adequado para julgamento das contas. A distinção fica clara na própria lei orgânica do tribunal, que no Título II reúne as duas funções: julgamento e fiscalização.

\footnotetext{
9 Neste caso, a tomada de contas especial é inteiramente realizada pelo Tribunal. O procedimento de fiscalização atua como a primeira parte da TCE. Após a conversão, com a constituição em processo, abre-se o contraditório e a ampla defesa. Nos demais casos a TCE tem a sua primeira parte realizada pela própria administração ou pelos órgãos de controle interno, encaminhada ao TCU para realização da segunda fase, se ultrapassado o valor de alçada (IN TCU 71/2012).
} 


\section{A INCONSTITUCIONALIDADE DA PUBLICIDADE RESTRITA DOS PROCESSOS NO TRIBUNAL DE CONTAS DA UNIÃO}

Enquanto no capítulo I desse título a lei normatiza as disposições respeitantes à função judicante, considerando as possibilidades dos julgamentos em contas regulares, regulares com ressalvas e irregulares (art. 10, $\S 2^{\circ}$ ), o capítulo II preceitua as questões ligadas à fiscalização a cargo do tribunal (função fiscalizatória).

Repita-se, porque a questão é fundamental para a exata compreensão do artigo: há nítida distinção entre os processos de contas e os instrumentos de fiscalização. Os primeiros são os meios processuais típicos do controle externo e permitem a concretização da função judicante do Tribunal. Os últimos, instrumentos, são meios procedimentais a serviço da função fiscalizatória da Corte de Contas. Assim, é possível estabelecer, mutatis mutandis, comparação direta entre os processos de contas com a ação penal, e os instrumentos fiscalizatórios com o inquérito policial. A comparação é frutífera, pois permite compreender que num caso, nos processos instaurados, a regra geral deve ser a publicidade, e no outro, na fase procedimental, a regra é o sigilo ${ }^{10}$.

A distinção é bem demonstrada por Zymler (1997, p. 214):

[...] Mostrou-se a existência de dois processos típicos de contas e de fiscalização - , dotados de atributos distintos. O primeiro está visceralmente ligado à competência "judicante" da Corte de Contas, cuja natureza jurídica exige a inteira incidência dos princípios do contraditório e da ampla defesa.

Ao contrário, os processos de fiscalização fazem atuar a competência controladora do TCU. Desse modo, contêm fase processual consistente na coleta de dados e informações por meio de auditorias e inspeções, que, em regra, não facultam aos responsáveis prévio conhecimento da matéria tratada.

Observa-se que o autor, hoje Ministro do TCU, muito embora reconheça a distinção entre as funções do Tribunal, argumenta pela restrição da publicidade também no âmbito dos processos de contas.

\footnotetext{
10 A comparação é meramente didática. Por força do art. 15 do NCPC os processos administrativos são disciplinados subsidiária e supletivamente pelas normas do processo civil. Não se quer dizer aqui, com a comparação, que os preceitos do processo penal podem ser incorporados aos processos do TCU. Mas a comparação é rica porque permite compreender dois momentos distintos no exercício do controle externo: a fase procedimental e a fase processual.
} 


\section{REVISTA ESTUDOS INSTITUCIONAIS}

A distinção também exsurge em recente julgado do STF, em sede do MS 34.296 AGR/DF, Rel. Min. Dias Toffoli:

1. O estabelecimento do contraditório em procedimentos iniciais de apuração de materialidade de atos objeto de denúncia perante o TCU não é obrigatório, pois, nessa fase, há mero ato investigatório, sem formalização de culpa. Precedentes.

2. De acordo com previsão do art. 12, II, da Lei Orgânica do TCU (no 8.443/92), é no processo da tomada de contas que o apontado como responsável tem a oportunidade de exercer seu direito ao contraditório e à ampla defesa, o que foi observado no caso dos autos.

Uma vez aceita a possibilidade de sigilo nas ações de fiscalização do TCU, dada a sua clara função investigatória, tem-se com clareza a exata delimitação do problema a ser enfrentado: se é possível a limitação da publicidade na instrução e no julgamento dos processos de contas prestação, tomada de contas e tomada de contas especial - no âmbito do Tribunal de Contas da União.

\section{Particularidades e natureza jurídica dos processos de contas}

Os processos no âmbito do TCU guardam a característica particular de que o órgão que acusa é o mesmo que julga. Uma postura garantista da Corte de Contas, visando amenizar este aspecto, está assentada no artigo 156 do Regimento Interno, prevendo segregação de funções entre os vários órgãos do Tribunal, separando os processos de controle externo em três etapas, dentre eles os processos de contas: (1) a instrução, realizada pelo corpo técnico; (2) o parecer, emitido pelo Ministério Público de Contas; (3) o julgamento ou a apreciação, proferidos pelos órgãos colegiados - Plenário e Câmaras.

A visão tecnicista acerca da instrução aponta para um processo eficaz, dando grande margem de crédito aos auditores, imputando-lhes os princípios da impessoalidade e da eficiência como remédio aos riscos que ameaçam o processo justo. É neste sentido que Oliveira (2007, p. 70), Auditor Federal, preleciona que:

[...] a instrução processual desponta como firme sustentáculo do processo, pela sua relevante contribuição para uma atuação célere e juridicamente consistente, porquanto abriga a investigação, a acusação 


\title{
A INCONSTITUCIONALIDADE DA PUBLICIDADE RESTRITA DOS PROCESSOS NO TRIBUNAL DE CONTAS DA UNIÃO
}

\begin{abstract}
e a proposta de julgamento de mérito do processo. Não se pode esperar que esses princípios e regras processuais e direito material sejam a fórmula mágica para a produção de instruções e decisões justas, porquanto o ser humano não é perfeito, razão pela qual também não o é a justiça que aplica, mas compete a cada agente processual fazer o melhor em um processo que envolve ao mesmo tempo o erário, o nome e a honra de uma pessoa, porquanto cada um desses agentes tem a sua parcela de responsabilidade em relação ao processo e, com certeza, dela prestará contas, cedo ou tarde.
\end{abstract}

Anotamos que o esmero e a acuidade técnica dos auditores não podem ser superestimados, sob pena de instauração de uma tecnocracia fundada em mitos de eficiência e imparcialidade, como já vimos ao amparo de Norberto Bobbio e Henri Lefebvre.

Quanto à natureza jurídica dos processos do TCU, a questão é polêmica, mas acolhemos a tese que, a nosso ver, apresenta-se como majoritária, de que os processos no âmbito do TCU possuem natureza administrativa. Nessa linha, assenta Eduardo Gualazzi, em trabalho aprofundado sobre o regime jurídico dos tribunais de contas: “Com efeito, os Tribunais de Contas, no Brasil, emitem vereditos administrativos, mas não exercem jurisdição stricto sensu, privativa do Poder Judiciário" (GUALAZZI, 1992, p. 203). Esse parece ser também o entendimento do STF, o qual registra precedente definindo que: "As instâncias judicial e administrativa não se confundem, razão pela qual a fiscalização do TCU não inibe a propositura da ação civil pública [...]" (MS 26.969, Rel. Min. Luiz Fux).

Em importante julgado sobre a prescrição de processo de tomada de contas especial (Resp. ํㅜ 1.480.350 - RS, rel. min. Benedito Gonçalves), o STJ considerou o processo como de natureza administrativa e, na lacuna da lei, aplicou prazo quinquenal, por analogia aos arts. $1^{\circ}$ do Decreto 20.910/32 e $1^{\circ}$ da Lei 9.873/99. A posição diverge com a adotada pelo TCU, que sói definir a natureza dos processos de contas como distinta do processo administrativo, arguindo que o tribunal não detém poder de polícia, mas sim poder de controle externo ${ }^{11}$.

A tese é problemática, pois cria tertium genus que serve como justificativa para um processo extraordinário, que escapa das alças da

${ }^{11}$ Neste sentido, os acórdãos no 5.928/2016, 6.104/2017, ambos da 2ª Câmara-TCU; e acórdão no $232 / 2017$, da $1^{\text {a }}$ Câmara-TCU. 


\section{REVISTA ESTUDOS INSTITUCIONAIS}

Constituição. Aceitando a natureza administrativa dos processos de contas, temos o art. 15 do NCPC incidindo sobre as normas processuais do TCU, haja vista que citado artigo prescreve a aplicação subsidiária e supletiva das suas disposições nos processos administrativo, trabalhista e eleitoral. Consequência imediata é que a norma regimental da publicidade restrita encontrará óbices na lei adjetiva civil.

Ademais, lembramos que o devido processo legal também acoberta os processos do TCU, independentemente da sua natureza jurídica, tal como podemos depreender do presente julgado do STF:

Não é possível, efetivamente, entender que as decisões das cortes de contas, no exercício de sua competência constitucional, não possuam teor de coercibilidade. Possibilidade de impor sanções, assim como a lei disciplinar. Certo está que, na hipótese de abuso no exercício dessas atribuições por agentes da fiscalização dos tribunais de contas, ou de desvio de poder, os sujeitos passivos das sanções impostas possuem os meios que a ordem jurídica contém para o controle de legalidade dos atos de quem quer que exerça parcela de autoridade ou poder, garantidos, a tanto, ampla defesa e o devido processo legal. (RE 190.985, Rel. Min. Néri da Silveira).

A seguir veremos que dentre os argumentos utilizados pelo TCU encontra-se a tese da especialidade dos processos de controle externo, quando se alega que a publicidade mitigada é meio eficaz de atuação da Corte de Contas. Daí a importância de ser reconhecer a sua natureza jurídica administrativa e a incidência do modelo constitucional de processo.

\section{A PUBLICIDADE NO ÂMBITO DO TCU: EXPOSIÇÃO DOS ASPECTOS LEGAIS E INFRALEGAIS}

A Lei Orgânica do TCU não possui, expressamente, preceito geral sobre a publicidade dos atos processuais. São três os pontos abordados pela lei, quais sejam: sigilo das denúncias (art. 53), sigilo dos atos processuais relativos a despesas reservadas (art. 92) e sessões administrativas e extraordinárias a portas fechadas (art. 108).

As denúncias não se afiguram como processo de contas em sentido estrito. O sigilo delas é questão polêmica a qual foge ao escopo deste 


\section{A INCONSTITUCIONALIDADE DA PUBLICIDADE RESTRITA DOS PROCESSOS NO TRIBUNAL DE CONTAS DA UNIÃO}

trabalho. De passagem, registramos que a matéria já foi parcialmente apreciada pelo STF, o qual declarou incidentalmente, no âmbito do MS 24.405-4/DF, inconstitucional o seguinte trecho do $\S 1^{\circ}$, dor art. 55: "manter ou não o sigilo quanto ao objeto e à autoria da denúncia". O entendimento firmado por maioria foi o de que a vedação do anonimato permite ao denunciado o conhecimento da pessoa do denunciante. A decisão teve repercussão geral mediante a Resolução no 16/2006 do Senado Federal. Seja como for, a regra de sigilo é especial e se volta exclusivamente para as denúncias.

O preceito relativo ao sigilo das despesas reservadas (art. 92) é outra cláusula de exceção ao princípio da publicidade e encontra fundamento na natureza da despesa. Previsão análoga está contida no art. 24 da LAI, o qual esposa classificação em caráter reservado, secreto ou ultrassecreto à informação, considerando seu teor e em razão de sua imprescindibilidade à segurança da sociedade ou do Estado. Notemos que o grau de sigilo decorre de classificação devidamente fundamentada e justificada. Uma vez recepcionada a informação com os devidos rótulos de sigilo, ela - e somente ela, não o processo em si - permanecerá assim no processo de controle externo (artigo $9^{\circ}$, $\S 1^{\underline{0}}$ da Resolução TCU $n^{0}$ 191/2006).

Por fim, o artigo 108 da Lei Orgânica do TCU prevê que as sessões administrativas e extraordinárias poderão ocorrer em caráter reservado. Parte do preceito perdeu efetividade em decorrência da Emenda Constitucional no 45/2004, que alterou o art. 93, X da Constituição Federal, estabelecendo que "as decisões administrativas dos tribunais serão motivadas e em sessão pública [...]". Quanto às sessões extraordinárias, subsiste a possibilidade do caráter reservado em dois casos: quando a preservação dos direitos individuais e o interesse público o exigirem, bem como para julgar ou apreciar os processos (administrativos ou de controle externo) que derem entrada ou se formarem no Tribunal com a chancela de sigiloso (artigos. 97 e 134, § 5 ${ }^{\circ}$, ambos do Regimento Interno do TCU) ${ }^{12}$. A norma mantém validade se, em cada caso, for justificada a necessidade de sigilo.

Vemos, portanto, inexistência na Lei Orgânica do TCU de preceito geral relativo à restrição da publicidade dos atos processuais. Existem normas especiais referentes à denúncia, às despesas de caráter reservado e às sessões extraordinárias. A contrario sensu, entendemos possível depreender que o legislador restringiu a publicidade quando julgou 12 De acordo com resposta de consulta à ouvidoria do TCU, demanda no 293.050, de 27
jul. 2017 . 


\section{REVISTA ESTUDOS INSTITUCIONAIS}

necessário, havendo norma tácita prevendo a publicidade dos processos de contas. A seguir evidenciamos que a restrição geral se opera no plano infralegal.

No âmbito infralegal destacam-se duas resoluções no regulamento da publicidade dos atos processuais do TCU: o Regimento Interno (Resolução no 155/2002 - RITCU) e a Resolução nº 191/2006, que estabelece procedimentos para recebimento, autuação e tramitação de processos e documentos relativos à área de controle externo.

O Regimento Interno restringe a publicidade dos atos processuais às partes, aos procuradores e aos interessados, devidamente cadastrados mediante solicitação ao relator, sendo possível a proibição do acesso aos autos a qualquer desses em caso de "motivo justo" ou se o pedido de vista ocorrer no dia do julgamento. In verbis (sem grifos no original):

Art. 163. As partes poderão pedir vista ou cópia de peça do processo, mediante solicitação dirigida ao relator, segundo os procedimentos previstos neste capítulo.

[...]

$\S 2^{\mathrm{o}}$ Poderão ser indeferidos os pedidos de que trata o caput se existir motivo justo ou, estando no dia de julgamento do processo, não houver tempo suficiente para a concessão de vista ou extração de cópias.

A publicidade especial no âmbito do TCU veda a publicidade externa enquanto o processo estiver em curso, liberando-a quando o processo for julgado, mesmo assim mediante requerimento ao Presidente do Tribunal (art. 97, § 2ㅇda Resolução $n^{\mathbf{o}}$ 191/2006). As partes e os procuradores, quando obtém vistas do processo, assinam termo de sigilo e assunção de responsabilidades.

Quanto à publicidade interna, há duas hipóteses de negativa de acesso aos autos: (1) pedido de vista no dia do julgamento do processo; (2) motivo justo. A primeira causa, com justificação nitidamente pragmática, perde importância uma vez que atualmente $99,76 \%$ dos processos da Corte de Contas da União são eletrônicos ${ }^{13}$. Sendo o processo digital, passível de acesso simultâneo por várias pessoas, não subsiste o desiderato da norma.

Quanto ao motivo justo, a norma é sombria. A Resolução no 191/2006 se limita a repetir a expressão contida no Regimento Interno, sem dar

\footnotetext{
${ }_{13}$ De acordo com resposta de consulta à ouvidoria do TCU, demanda no 293.059 , de 07 ago. 2017.
} 


\section{A INCONSTITUCIONALIDADE DA PUBLICIDADE RESTRITA DOS PROCESSOS NO TRIBUNAL DE CONTAS DA UNIÃO}

maiores detalhes. Em julgamentos sobre a matéria, o TCU sói resumir a questão à fórmula do "interesse público", sem esclarecer ao certo em que medida é razoável tolher a parte do acesso aos autos.

Não é razoável arguir que possível vista dos autos comprometeria as investigações. Não em processo de contas, fase processual propriamente dita, momento no qual o contraditório e a ampla defesa incidem completamente, como já asseverou o STF por meio da Súmula Vinculante $\mathrm{n}^{\mathrm{o}}$ 03, havendo ao advogado direito de acessar todas as informações juntadas nos autos, segundo entendimento da Súmula Vinculante no 14 .

Havendo necessidade de maiores investigações o Tribunal pode lançar mão de auditoria, inspeção ou procedimento de fiscalização congênere, estes sim passíveis de restrição e acesso.

\section{A PUBLICIDADE RESTRITA DO TCU FRENTE ÀS NORMAS LEGAIS DE CARÁTER PROCESSUAL E MOTIVOS DA RESTRIÇÃO}

O exame normativo já identificou que o modelo de publicidade especial operado no âmbito dos processos do TCU sustenta-se em regras regimentais sem amparo em lei. Não se trata, porém, de mera norma regimental sem respaldo legal. Tem-se, isso sim, disposição contrária a vários preceitos estritamente legais.

O confronto com a LAI por si só evidencia descompasso entre o regulamento do TCU e a legalidade, posto que a Lei de Acesso à Informação adota expressamente o sigilo como exceção (artigo 3o， I), reservado aos atos atinentes à defesa da intimidade e da segurança da sociedade e do Estado (art. 23). Ainda assim, o artigo 31, $\S 4^{\circ}$ da citada lei esposa que:

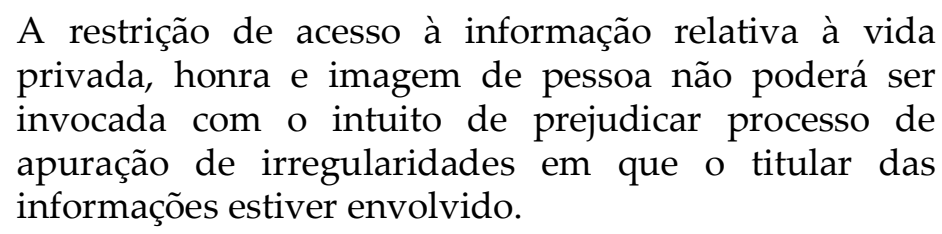

Não se olvida também que o modelo de publicidade fundamentado no Regimento Interno do TCU atenta contra o Estatuto da Ordem dos Advogados do Brasil (Lei $\mathrm{n}^{\mathrm{o}}$ 8.906/94), vedando ao advogado não constituído acesso aos autos dos processos. 


\section{REVISTA ESTUDOS INSTITUCIONAIS}

De plano a questão se resolveria por simples exegese, adotando-se o princípio da legalidade. Inclusive, se entendermos que a lei orgânica, ao estabelecer apenas as hipóteses de sigilo, teria adotado norma tácita de publicidade ampla, a questão se torna ainda mais evidente. Porém, cabe a indagação: se a questão é de simplória solução, por que o modelo restritivo ainda subsiste? As dificuldades da questão se avolumam quando se envolvem aspectos poucos esclarecidos pela doutrina e jurisprudência pátrias, como $\mathrm{o}$ da natureza jurídica das normas regimentais, dada a hipótese sustentada em mais de um caso em que os regimentos, por reproduzirem competência primária dos tribunais, têm força de lei, perfazendo na jurisprudência do Tribunal Constitucional posição favorável à tese. Ademais, o próprio TCU já enfrentou o questionamento, aduzindo que:

[...] não se deve perder de vista a prerrogativa constitucional conferida ao TCU (art. 73), para exercer, no que couber, as atribuições previstas no art. 96, que emana competência privativa aos tribunais para elaborar seus regimentos internos, com observância das normas de processo e das garantias processuais das partes, dispondo sobre a competência e o funcionamento dos respectivos órgãos jurisdicionais e administrativos. $[\ldots]$

Assim, como bem destacou a douta titular da CONGER, "a outorga de competência para dispor sobre as próprias atribuições judiciárias e administrativas, de par com a de organizar suas secretárias e serviços auxiliares $(\mathrm{CF}$, art. 96, I, a e b), necessariamente implicará no deferimento de iniciativa legislativa nessa matéria, na medida em que se trate de objetivos que exigem forma legal". (Decisão no 507/96-TCU-Plenário. Min. Paulo Affonso Martins de Oliveira).

Se eventualmente for reconhecido que as normas regimentais do TCU têm força de lei, não há, mesmo nesse caso, como sustentar a legitimidade democrática das normas. Não sendo eleitos os Ministros do TCU, qualquer norma, mesmo regimental, não tem o condão de restringir preceito constitucional, muito menos dispor em contrário. Falta-lhes a presunção de constitucionalidade.

Em todo caso, para além do argumento normativo, estupefatos pela duração de modelo restrito de publicidade processual, cabe-nos indagar como fez Beccaria (2001): em quais motivos se baseiam aqueles que defendem as acusações secretas? 


\section{A INCONSTITUCIONALIDADE DA PUBLICIDADE RESTRITA DOS PROCESSOS NO TRIBUNAL DE CONTAS DA UNIÃO}

\section{Restrição da publicidade em nome da proteção das garantias e dos direitos individuais}

Muito embora não examinemos a restrição da publicidade das denúncias, é essencial apresentar alguns dos seus aspectos. Nessa seara, o legislador estabeleceu no caput do art. 55 da lei $n^{\mathbf{o}} 8.443 / 92$ que as denúncias correriam em sigilo em nome dos direitos e garantias fundamentais. A matéria é sensível porque nos casos nos quais o TCU julga improcedente a denúncia, o sigilo permanece, mantendo o processo fora do alcance dos denunciantes e da sociedade.

A questão é das mais complexas, pois nesta hipótese o cerceamento da publicidade foi realizado por ato legal - lei material e formal. Goza a lei no 8.443/92 de presunção de constitucionalidade e, como vimos, sob os ensinamentos de Bustamante, há um ônus argumentativo maior em situações assim, vez que se deve demonstrar que a regra legal estaria a extrapolar as exceções previstas na Constituição.

O modelo racional de argumentação jurídica proposto por Alexy nos auxilia mais uma vez, pois é no jogo dialético de razões teóricas e razões práticas que podemos perceber como o princípio democrático inviabiliza um processo em sigilo, ainda mais tratando de contas e recursos públicos. Vem a lume aspecto correlato à legitimidade de atuação das Cortes de Contas e a transparência de sua atuação, com deveres de prestação de contas de suas atividades. A esse respeito, a Organização Internacional de Entidades Fiscalizadoras Superiores (INTOSAI, 2010) estabelece que:

O conceito de accountability refere-se à estrutura jurídica e de comunicação, à estrutura organizacional e estratégia, aos procedimentos e às ações para garantir que:

- As EFS [Entidades de Fiscalização Superior] cumpram as obrigações legais do seu mandato de auditoria e produção de relatórios necessários dentro de seu orçamento.

- As EFS avaliem e monitorem o seu próprio desempenho, bem como o impacto da sua auditoria.

Transparência e accountability são irmãs siamesas. Ambas dialogam intimamente com a democracia. Accountability, em tradução livre, é prestar contas, dar satisfação aos cidadãos sobre o uso dos recursos públicos. Não é outro o sentido da Declaração dos Direitos Humanos: "Art. 11. Toda a pessoa tem o direito de tomar parte na direção dos 


\section{REVISTA ESTUDOS INSTITUCIONAIS}

negócios públicos do seu país, quer diretamente, quer por intermédio de representantes livremente escolhidos". Sendo assim, considerando a jurisdição do TCU estipulada no artigo 71, II da CRFB/88, a saber: julgar as contas de quem utilize, arrecade, use, administre recurso público, é deveras pertinente indagar sobre o quão privado é um processo cujo objeto são contas públicas.

Reconhecemos, porém, que no momento das apurações o sigilo é medida cuidadosa e se coaduna com o interesse público. Há de se verificar, portanto, sobre o momento em que o processo se torna público. Sobre isso, a disposição no art. 7º, VII, " $b$ ", da LAI traz interessante preceito:

Art. 7o $\mathrm{O}$ acesso à informação de que trata esta Lei compreende, entre outros, os direitos de obter:

$[\ldots]$

VII - informação relativa:

$[\ldots]$

b) ao resultado de inspeções, auditorias, prestações e tomadas de contas realizadas pelos órgãos de controle interno e externo, incluindo prestações de contas relativas a exercícios anteriores.

A lei define que, além das prestações e tomada de contas, é direito do cidadão obter informações a respeito do resultado de auditorias e inspeções, i.e., tomar conhecimento de relatórios ${ }^{14}$. Assim, entendemos que, nos processos de fiscalização, fase puramente de controle e investigação, o sigilo é legítimo e defende o interesse público. Concluídos os trabalhos de apuração, com a respectiva conclusão do relatório, as informações passam a ser públicas.

Tal entendimento reflete possível solução à controvérsia das denúncias. Maneira de compatibilizar o mandamento constitucional da publicidade e a respectiva garantia individual, também de natureza constitucional, de proteção da imagem, honra etc., seria tornar pública a denúncia após a conclusão dos trabalhos de averiguação, tendo a apresentação do relatório - seja de auditoria, seja de inspeção - como

${ }^{14}$ De acordo com as Orientações para auditorias de conformidade do TCU, aprovaras pela Portaria-ADPLAN no 1 , de 25 de janeiro de 2010, p. 40: “O Relatório é o principal produto da auditoria. É o instrumento formal e técnico por intermédio do qual a equipe de auditoria comunica aos leitores: o objetivo e as questões de auditoria; a metodologia utilizada; os achados de auditoria; as conclusões; e a proposta de encaminhamento". 


\section{A INCONSTITUCIONALIDADE DA PUBLICIDADE RESTRITA DOS PROCESSOS NO TRIBUNAL DE CONTAS DA UNIÃO}

marco objetivo. Militam em prol dessa interpretação os $\S \S 3^{\circ}$ e $4^{\circ}$, do art. 53 da Lei Orgânica do TCU, os quais preveem (sem grifos no original):

Art. 53. Qualquer cidadão, partido político, associação ou sindicato é parte legítima para denunciar irregularidades ou ilegalidades perante o Tribunal de Contas da União.

$\S 1^{\circ}$ (Vetado)

$\S 2^{\circ}$ (Vetado)

$\S 3^{\circ}$ A denúncia será apurada em caráter sigiloso, até que se comprove a sua procedência, e somente poderá ser arquivada após efetuadas as diligências pertinentes, mediante despacho fundamentado do responsável. $\S 4^{\circ}$ Reunidas as provas que indiquem a existência de irregularidade ou ilegalidade, serão públicos os demais atos do processo, assegurando-se aos acusados a oportunidade de ampla defesa.

Observamos que a sistemática legal se preocupa em proteger a honra e a imagem dos denunciados, por isso dispõe no art. 55 da referida lei: “No resguardo dos direitos e garantias individuais, o Tribunal dará tratamento sigiloso às denúncias formuladas, até decisão definitiva sobre a matéria". O critério genético permite depreender que o sigilo da denúncia, conjugado à vedação do anonimato, tem por escopo evitar acusações levianas, com intuito de aviltar deliberadamente a imagem de pessoa pública. No entanto, uma vez apurados os fatos e comprovada a procedência da acusação, os demais atos processuais serão públicos, por expressa determinação legal.

Seguindo este tópico de exame do conflito entre os direitos e garantias fundamentais, é preciso rememorar que as pessoas que respondem perante o TCU utilizam, guardam, arrecadam, administram ou usam recursos públicos ${ }^{15}$. Preceito geral dispõe que essas pessoas devem prestar contas e tais contas são, por natureza, públicas. Daí se conclui que ato limitador da publicidade processual diminui a transparência dos atos públicos, conforme se depreende da figura abaixo:

${ }^{15}$ No caso das tomada de contas especial há hipótese de pessoa sem vínculo com a administração pública, mas ainda assim causa um dano ao erário. 


\section{REVISTA ESTUDOS INSTITUCIONAIS}

Figura 1 - comparativo entre o modelo de publicidade do TCU e o modelo Constitucional

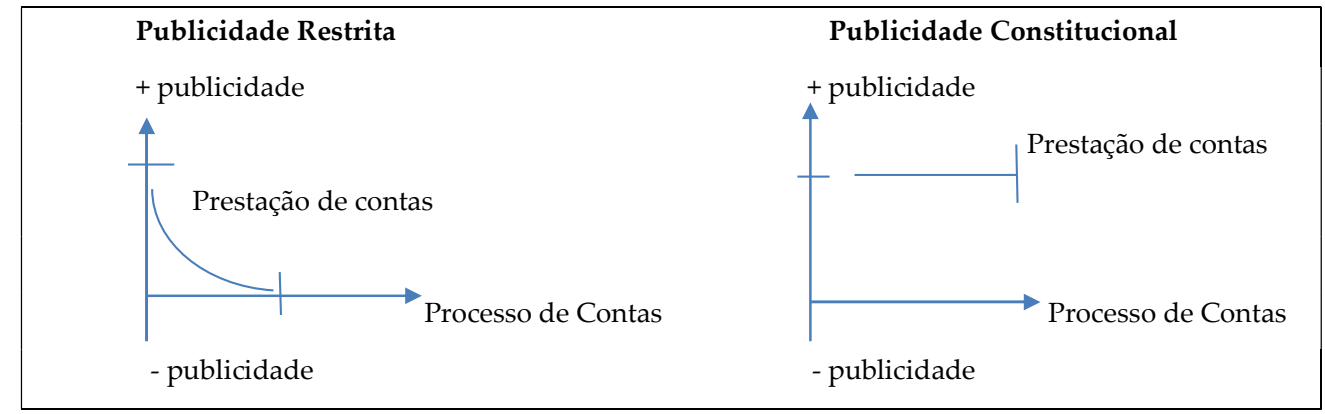

Fonte: elaborado pelos autores

Em termos gráficos, o regime de publicidade especial do TCU provoca uma curva negativa na accountability, sendo que deveria ser ao menos uma constante. É dizer: se o TCU não propõe maiores expansões da publicidade, não poderia limitá-la.

Temos em conta a defesa de uma publicidade constitucional e não de uma publicidade plena, porque sempre haverá, no exame do caso concreto, a possibilidade de se classificar o processo como sigiloso. Havendo necessidade de restrição da publicidade, a lei processual civil, a LAI e a própria lei orgânica do TCU preveem as devidas exceções. Não sendo suficientes as excepcionalidades legais, é possível o sopesamento de princípios e a elaboração de regra derivada, advinda da lei de colisão. Não se pode, porém, estabelecer de antemão, de cabeça para baixo, o sigilo como preceito geral e a publicidade como exceção.

Em termos comparativos, tem-se, na seara privada, como no processo civil, o julgamento às escancaras, aberto plenamente ao auditório universal. Por outro lado, na seara pública, a restrição operada pelo regime jurídico infralegal do TCU tolhe a publicidade, ofertando o julgamento em segredo.

Alexy defende que na colisão de princípios deve ser avaliado: se uma medida não beneficia um princípio e ataca outro, então ela não deve ser adotada. Nesse caso, a não aplicação vai propiciar a máxima aplicação de ambos os princípios. Isso é muito importante porque entre os direitos e garantias constitucionais há, para além da imagem, honra, e intimidade, o direito ao devido processo legal: público, escorreito, com possibilidade de efetivo contraditório e ampla defesa. Tais garantias individuais também devem ser consideradas ao se restringir ou não a publicidade de um ato processual. Supomos que haverá aqueles interessados de mostrar em público que essa ou aquela denúncia são infundadas. Nesse caso, a 


\section{A INCONSTITUCIONALIDADE DA PUBLICIDADE RESTRITA DOS PROCESSOS NO TRIBUNAL DE CONTAS DA UNIÃO}

publicidade dos atos processuais soa como aliada à defesa de sua imagem.

\section{Restrição da publicidade por "motivo justo"}

O artigo 163, $\S 2^{\circ}$ do RITCU preceitua que as partes e os interessados poderão ter o pedido de vistas negado por motivo justo. Embora a Resolução no 191/2006 não detalhe o assunto, é possível extrair sentido da expressão empregando-se interpretação por extensão analógica. O Regimento fala que os pedidos de acesso aos autos poderão ser indeferidos se existir motivo justo ou, estando no dia de julgamento do processo, não houver tempo suficiente para a concessão de vista ou extração de cópias. Vê-se um teor nitidamente instrumental à regra, cujo vetor teleológico cinge-se em prol de um processo célere ${ }^{16}$.

Vedar o acesso aos autos alegando motivo justo, embora seja uma possibilidade, não espelhando o preceito geral - uma vez que, a contrario sensu, sem justo motivo as partes têm acesso aos autos - fere a regra constitucional de publicidade dos atos processuais, pois cria hipótese sem previsão legal e sem amparo nas exceções previstas no texto da Constituição. A questão se adensa quando se compreende que justo motivo é conceito indeterminado, abrindo margem para atuação do intérprete e possível expansão das hipóteses de incidências.

Temos em mente o fato de que não se afigura como justo motivo a proteção ao interesse público na forma de garantia da eficiência das ações de controle do tribunal, pois estamos a falar da fase de julgamento, estando o processo instruído com os elementos de prova capazes de formar a opinião da área técnica de controle externo a ponto de relatar as irregularidades encontradas. Neste passo do processo, às vésperas do julgamento, negar vistas do processo, como no acórdão citado, é ferir o direito de defesa do responsável sob julgamento (lembremos que os processos são eletrônicos e que a concessão das vistas não atrasará a atuação do relator).

A eficiência processual deve ser sopesada ante outros princípios que sustentam o processo, como o contraditório, a ampla defesa e o devido

16 Tal interpretação é corroborada pelo voto do relator no acórdão no ${ }^{0}$ 11.224/2017 Primeira Câmara, 05/12/2017, Rel. Walton Alencar Rodrigues: “Destaque-se que o pedido foi realizado em 28/3/2016, sendo que a sessão ocorreria em 31/3/2016. O Regimento Interno do Tribunal de Contas da União prevê a possibilidade de indeferimento de pedido de vistas ou cópias eletrônicas se existir motivo justo ou, estando no dia de julgamento do processo, não houver tempo suficiente para a concessão de vista ou extração de cópias". 


\section{REVISTA ESTUDOS INSTITUCIONAIS}

processo legal. Motivo que impeça a parte ou o seu patrono de acessar os autos deve ser visto e pensado sob a ótica de um processo, este sim, justo. Mais uma vez vale a lei de colisão de Alexy e aplicação da proporcionalidade: caberia, em prol da celeridade processual, direito de matiz constitucional, elidir a publicidade interna do processo de contas? Há, neste caso, precedência condicionada do princípio da razoável duração do processo em relação à garantia do contraditório? No caso em exame, a exceção criada pelo regimento interno do TCU parece ofender à proporcionalidade, pois aceita elidir por inteiro uma garantia constitucional em face de outra, espanada na generalidade de um conceito vago, como o de motivo justo.

\section{Restrição da publicidade por interesse público e pela especialidade dos processos de controle externo}

A matéria deste tópico foi amplamente discutida no âmbito do acórdão n⿳0 2.412/2010 - TCU - Plenário (TC 006.569/2009-2) quando se examinou pedido de acesso aos autos de tomada de contas especial por advogado não constituído. No exame, o relator, Ministro-Substituto Weder de Oliveira, inverteu a regra da publicidade, tornando-a exceção (sem grifo no original):

Todos os processos mencionados [processos de controle externo] têm especificidades e o acesso a eles não é passível de ser concedido incondicionalmente a todo e qualquer cidadão, de maneira uniforme, em abstrato. Assim, em cada caso a prerrogativa estabelecida no inciso XIII do art. $7^{\circ}$ [do estatuto da OAB] deve ser observada segundo normas adequadas ao tipo, natureza e objetivo do processo.

[...]

Um pedido de obtenção de vista e cópia de autos de processo de tomada de contas especial em andamento com fundamento unicamente na condição de bacharel em direito inscrito na Ordem dos Advogados do Brasil, e nada mais, não pode ser deferido. Se isso não decorresse de expressa previsão regimental, decorreria de proibição imposta pelo princípio da isonomia, haja vista que a engenheiros, administradores, economistas, contadores e a qualquer outro nobre cidadão brasileiro semelhante pedido não seria deferido sem que estivesse calçado na demonstração de interesse legítimo para 


\section{A INCONSTITUCIONALIDADE DA PUBLICIDADE RESTRITA DOS PROCESSOS NO TRIBUNAL DE CONTAS DA UNIÃO}

ingressar no processo.

Para o relator, a publicidade dos processos não é regra, devendo-se pressupor que os processos de controle externo estão sob sigilo e somente o exame do caso concreto permitirá ou não o acesso. O motivo da inversão sustenta-se basicamente em duas razões obscuras: especificidade dos processos de controle externo e interesse público.

Argui o relator que os processos do TCU são distintos de qualquer outra modalidade, tendo regulação própria. A razão da particularidade decorre do fato de o processo tratar irregularidades cometidas por pessoas conhecidas, cujos nomes merecem maior grau de proteção. Pelo argumento, a prerrogativa estampada no art. $7^{\circ}$, XIII da Lei $\mathrm{n}^{\mathrm{0}}$ 8.906/94 (Estatuto da OAB) que permite ao advogado, mesmo sem procuração, examinar, em qualquer órgão dos Poderes Judiciário e Legislativo, ou da Administração Pública em geral, autos de processos findos ou em andamento, quando não estejam sujeitos a sigilo, deve ser amenizada diante das diferentes naturezas de processos e instituições, examinandose em cada caso a aplicação da norma, submetendo a prerrogativa profissional "à devida ponderação, em confronto com princípios e direitos constitucionais, pelo meio normativo próprio, como fez o Tribunal de Contas da União" (Acórdão no 2.412/2010 - TCU Plenário. Min. Relator Weder de Oliveira).

A tese não é minoria. É nesse sentido que Zymler (1997, p. 191), Ministro do TCU, assevera que o direito de acesso aos autos por advogado deve ser restringido, nos termos da legislação do Tribunal, considerando que:

Em face das peculiaridades dos processos no TCU, em que o interesse público prepondera sobre o particular, não é permitida a retirada de processo das dependências do Tribunal, por qualquer das partes. As prerrogativas asseguradas aos advogados pela Lei no 8.906/94 devem ser harmonizadas com a finalidade pública buscada pela atuação do Tribunal.

Veja-se que é assegurado ao Tribunal, nos termos do art. 73, caput, c/c o art. 96, I, "a", da Constituição Federal, o poder de dispor sobre suas normas regimentais e processuais, parecendo não ser possível que lei ordinária, tal como o Estatuto dos Advogados (Lei $\mathrm{n}^{\mathrm{o}}$ 8.906/94), possa invadir círculo de competência 


\section{REVISTA ESTUDOS INSTITUCIONAIS}

destinado constitucionalmente ao Tribunal de Contas da União.

A especialidade desses processos despertaria maior interesse público, mais do que um processo judicial civil ou penal, que julga pessoas fora da vida pública. Assim:

Os processos que correm no Tribunal de Contas da União não são da mesma natureza de uma lide judicial, na qual, em geral, as partes desde o primeiro momento tornam públicas suas divergências e seus conflitos de interesse.

Ali não há um interesse público primário (num sentido mais estrito) a ser alcançado, por meio de uma cadeia de ações de cunho ao mesmo tempo investigativo e quase judicial, em que se garante o contraditório, com intervenção de advogados.

Tudo isso qualifica os processos de controle externo como processos intrinsecamente sujeitos a restrição de acesso, o qual esta Corte estende a terceiros que motivem sua intenção de ingressar no processo como interessado, terceiro ao qual, uma vez admitido no processo, além de vista e cópia dos autos, será assegurado o exercício de todas as demais faculdades processuais.

Portanto, o acesso aos autos nesta Corte tem seu direito condicionado não apenas pelas ressalvas de sigilo expressamente previstas no estatuto da advocacia e às finalidades previstas naquele normativo, mas também pelas peculiaridades dos processos e informações tratadas neste Tribunal, e pelos princípios e preceitos constitucionais que precisam ser sopesados e harmonizados. (Acórdão no 2.412/2010 - TCU Plenário. Min. Relator Weder de Oliveira).

A dupla processo especializado-interesse público, sempre avocada como fórmula geral, num sentido um tanto nebuloso, de alguma forma conduz à conclusão de que a regra é o sigilo e a publicidade a exceção. $\mathrm{O}$ julgamento é de 2010, mas em consulta recente à ouvidoria do TCU ${ }^{17}$ confirmamos que o acesso aos processos em andamento dá-se somente

17 Demanda 291.143, de 23 jun. 2017.

4 JOURNAL OF INSTITUTIONAL STUDIES 2 (2018)

Revista Estudos Institucionais, v. 4, n. 2, p. 797-845, 2018 


\section{A INCONSTITUCIONALIDADE DA PUBLICIDADE RESTRITA DOS PROCESSOS NO TRIBUNAL DE CONTAS DA UNIÃO}

com autorização do relator ou por servidor delegado. O tribunal, regulamentando a LAI por meio da Resolução no 249, de 02 de maio de 2012, manteve incólume as disposições restritivas do Regimento Interno de 2002, o que demonstra a disposição atualizada da Corte de Contas Federal em não abrir suas portas à vista do público em geral.

Em outra situação, no julgamento do agravo contra despacho que deferiu ao Departamento Nacional do Serviço Social do Comércio (SESCDN) pedido de vista e cópia dos autos do TC 020.456/2016-6, no qual o Serviço Nacional de Aprendizagem Comercial no estado do Rio de Janeiro (SESC-Rio) figurava como responsável (réu), o agravante (SESCRio) questionou a legitimidade do SESC-DN para ter vistas dos autos. A decisão proferida por meio do acórdão $\mathrm{n}^{-}$1.081/2017 - Plenário, através de um malabarismo jurídico, considerou que o SESC-DN, por figurar como supervisor da seccional estadual, detinha legitimidade para conhecer do processo e que o relator, ao decidir positivamente pela vista dos autos, reconheceu, tacitamente, que o órgão solicitara, também implicitamente, a qualificação como terceiro interessado. Tudo isso porque o artigo 144, $\S 2^{\mathrm{o}}$ do Regimento Interno prevê que o pedido de vistas feito por terceiro deve ser precedido da habilitação como interessado, mediante pedido feito ao relator ou ao Presidente. Em nenhum momento cogitou-se pelo reconhecimento da publicidade dos atos processuais.

A tese de que o maior interesse público evidencia maior cautela na publicidade dos autos processuais anda na contramão de um processo justo, democrático. Do ponto de vista lógico, o princípio da identidade revela uma contradição interna: se o processo possui preponderância do interesse coletivo sobre o individual, por que corre em sigilo, já que é interesse público acompanhar tal processo?

Mais uma vez há de se diferenciar a fase procedimental da fase processual. Na primeira se realiza a função fiscalizadora por meio de auditorias e inspeções, voltadas para a apuração dos fatos, responsabilidades e eventuais danos. Neste momento há, de fato, evidente interesse público em manter o procedimento em sigilo. Inclusive a escolha dos órgãos, entidades ou pessoas a serem fiscalizadas perpassa como legítima hipótese de sigilo. Questão bem diferente é a fase processual, consubstanciada nos processos de contas. Aqui, com as investigações assentadas e registradas no processo, momento oportuno e necessário ao contraditório e à ampla defesa, não há se falar em interesse público a limitação da publicidade dos atos processuais.

Se de algum modo tais premissas não forem suficientes, é possível igualmente avocar o direito humano de acesso à informação, de índole 


\section{REVISTA ESTUDOS INSTITUCIONAIS}

constitucional (art. 5으. XXXIII), assegurado por importantíssimos tratados internacionais, tais como: Pacto Internacional dos Direitos Civis e Políticos (1966), artigo 19, Declaração Interamericana de Princípios de Liberdade de Expressão (2000), Item 4, Convenção das Nações Unidas contra a Corrupção (2003), artigos 10 e 13.

Segundo o Manual de Acesso à Informação da Controladoria Geral da União - CGU (BRASIL, 2013), a busca da efetivação do acesso à informação é um fenômeno crescente. Em 1990 apenas 13 países possuíam lei sobre a matéria, mas atualmente cerca de 90 nações já aprovaram normas visando dar acesso às informações públicas aos cidadãos.

Tal fenômeno dialoga diretamente com a legitimação da atuação estatal, garantida principalmente pela accountability. A transparência da atuação pública não pode vergar justamente no momento do julgamento dos possíveis infratores. Postulações abstratas, tais como: eventuais erros processuais, acusações não comprovadas, irregularidades não confirmadas, não podem justificar a restrição do princípio da publicidade. A lei de acesso à informação, como destaca a CGU, destinase a criar uma cultura da publicidade, na contramão da cultura do segredo. Somente a transparência, a accountability e a informação podem fortalecer o controle social, o mais legítimo dos controles em um Estado Democrático.

Quiçá a resposta buscada pelo Ministro-substituo Weder de Oliveira, quando nega publicidade a advogado não constituído, sob o argumento da manutenção da isonomia, seja a de justamente abrir o processo para todo o auditório universal, composto por engenheiros, contadores, professores, garis, carpinteiros, costureiras e de uma infinidade de cidadãos, sejam quais forem suas profissões e interesses.

\section{CONCLUSÃO}

Iniciamos a pesquisa indagando se a regra contida no art. 163 do RITCU, a qual restringe por completo a publicidade externa dos processos do TCU e possibilita, em algumas hipóteses, a restrição da publicidade interna, possuía amparo constitucional.

Para o deslinde da questão dissertamos sobre o princípio democrático e seu reflexo na publicidade dos atos processuais, segundo os ensinamentos de Bobbio (1986), chegando à conclusão de que qualquer ator social que contracene no palco da administração pública só o fará legitimamente sob os holofotes e os olhos do auditório universal. $\mathrm{O}$ agente público na figura do juiz ou ministro do TCU é o vidente visível, 


\section{A INCONSTITUCIONALIDADE DA PUBLICIDADE RESTRITA DOS PROCESSOS NO TRIBUNAL DE CONTAS DA UNIÃO}

com dever de accountability. O único vidente invisível é o povo, titular e soberano do poder em um regime democrático.

Seguindo, apresentamos as normas referentes à publicidade na Constituição Federal, observando preceitos de índole fundamental asseverando por uma ampla publicidade tanto dos atos administrativos, quanto dos atos processuais, restringíveis somente nas hipóteses de proteção da intimidade, interesse público, segurança da sociedade e do Estado. Para compreensão racional de tais preceitos optamos pelo exame da sua natureza, de regra ou de princípio, vislumbrando como possíveis conflitos entre normas se resolvem. A tarefa exigiu o aporte teórico fornecido pela teoria dos direitos fundamentais de Robert Alexy e sua conhecida distinção entre regras e princípios.

Munidos da compreensão de que regras são mandamentos de definição e princípios são mandamentos de otimização, conseguimos estabelecer que a Constituição da República tem a publicidade não apenas como princípio, mas também como regra, obrigando seu cumprimento tal qual foi disposto, nem mais, nem menos. Nesse momento ficamos com um quadro cujo desenho apresentava dois possíveis conflitos: (1) conflito (em sentido estrito) entre a regra constitucional da publicidade com a regra regimental da publicidade restrita do TCU e (2) conflito (em sentido estrito) entre o princípio constitucional da publicidade com a regra regimental da publicidade restrita do TCU.

O exame dos conflitos normativos foi realizado ao amparo dos estudos de Bustamante (2010), quando concluímos que o primeiro conflito se resolvia de modo óbvio, prevalecendo a regra de maior hierarquia. Em outras palavras, nessa fase do estudo já se mostrava que o modelo adotado pelo regimento interno do TCU ofendia regra da publicidade constitucional. O segundo caso, mais complexo, exigiria a ponderação entre o princípio que foi agredido e o princípio que fundamenta a regra, com três resultados possíveis: (i) a Constituição veda disposição em contrário e o legislador não poderia editar a regra; (ii) a Constituição permite a disposição em contrário, possibilitando, portanto, a atuação do legislador; (iii) a Constituição não veda nem permite, e o legislador também está livre para decidir a respeito. Anotamos que nos casos (ii) e (iii) a abertura está para o legislador, que em decorrência do princípio democrático edita leis com presunção de constitucionalidade. Não é a situação do TCU e do seu regimento interno, aprovado por ministros nomeados e não eleitos.

Todavia, cientes da tese de que os regimentos internos derivam de competência estatuída no texto constitucional e por isso teriam força de 


\section{REVISTA ESTUDOS INSTITUCIONAIS}

JULHO/DEZEMBRO - ISSN 2447-5467

lei, seguimos com o exame do modelo de publicidade restrita do TCU. Se por ventura o entendimento fosse o de que a CRFB/88 não editou regras a respeito da publicidade, mas apenas princípios, e que o RITCU possui força de lei, estaríamos diante da segunda hipótese de conflito, com um ônus maior de argumentação.

Assim, dedicados à tarefa, apontamos o conceito de processos de contas e sua distinção dos procedimentos de fiscalização. Chegamos à conclusão de que o TCU, no exercício de sua função judicante, atuante por meio dos processos de contas, não pode restringir a publicidade interna em qualquer hipótese, sob pena de ofensa ao devido processo legal, ao contraditório e à ampla defesa, assim como pela incidência das súmulas vinculantes 03 e 14. Já na realização da função fiscalizadora, de controle, consubstanciada nos procedimentos de fiscalização, o TCU poderia restringir tanto a publicidade interna quanto a externa.

A restrição da publicidade das auditorias, inspeções e demais instrumentos de fiscalização atende a interesse público, pois visa a eficácia das ações de controle e resguarda as garantias individuais dos investigados, vez que não divulga acusações não evidenciadas. Já nos processos de contas, quando figuram acusações verificadas e se permite o contraditório, o interesse público passa a exigir a transparência dos atos processuais. Aqui figura a regra do art. 11 do NCPC, a qual dita como nulo ato processual sem publicidade.

Em sequência, apontamos como o modelo de publicidade restrita do TCU contradiz uma miríade de leis, tais como a LAI, quando estipula a publicidade como regra e o sigilo como exceção, o estatuto da $\mathrm{OAB}$, que garante ao advogado acesso aos autos mesmo sem procuração, e aquelas atinentes ao direito adjetivo, o NCPC e a lei federal do processo administrativo, ambas permitindo amplo acesso aos atos processuais, exceto nas hipóteses legalmente previstas.

Para solução da questão propusemos que se adotasse o relatório de auditoria ou inspeção, instrumento conclusivo da equipe técnica que apresenta os resultados da fiscalização, como marco objetivo de abertura da publicidade. Indicamos como a LAI prevê o direito de qualquer pessoa acessar as informações constantes em processos de prestações, tomadas de contas e resultados de auditorias e inspeções. Tal medida demarcaria racionalmente que os procedimentos de fiscalização, tais como os inquéritos de investigação que gozam de legítimo sigilo, poderiam ser fechados, com direito de vista apenas ao advogado daquilo já documentado nos autos (súmula vinculante 14). Igual solução poderia ser adotada para as denúncias: sigilosas enquanto sua procedência não for confirmada, públicas uma vez apuradas. 


\section{A INCONSTITUCIONALIDADE DA PUBLICIDADE RESTRITA DOS PROCESSOS NO TRIBUNAL DE CONTAS DA UNIÃO}

Observamos que tais medidas garantem não apenas o cumprimento do princípio democrático, assim como as competências institucionais de controle do TCU. É claro, havendo colisão de princípios envolvendo direitos e garantias fundamentais, a ponderação e exame do caso concreto permitiria o regular deslinde da questão. Nesse cenário, no âmbito dos processos de contas, a publicidade figuraria como preceito geral, enquanto regra e princípio, e o sigilo atuaria como exceção. No entanto, tal como está preceituado no art. 163 do RITCU, o que se tem é um modelo constitucional de ponta cabeça, havendo o sigilo como o preceito geral e a publicidade como exceção.

Por fim, buscando aprofundar a discussão, examinamos as justificações frequentes para a manutenção do modelo de publicidade restrita, quais sejam: resguardo dos direitos e garantias fundamentais, motivo justo e interesse público. Os argumentos colacionados mostram que algumas dessas justificativas podem sim tolher a publicidade processual, mas desde que por ato devidamente fundamentado, com subsunção de regra de exceção ou por ponderação de princípios e efetivo exame do caso concreto. Não se pode é utilizar tais argumentos e de antemão, em abstrato, suprimir o princípio e a regra constitucional da publicidade.

Pois bem, confirmamos normativa e discursivamente a hipótese de que o modelo de publicidade restrita no âmbito do Tribunal de Contas da União é inconstitucional, havendo por ser considerada inválida a norma contida no art. 163 daquele regimento interno.

À guisa de exemplo de boa prática, citamos ao final a Instrução Normativa TCE/MA no 49, de 30 de agosto de 2017, a qual deu ampla publicidade dos atos processuais do Tribunal de Contas do Estado do Maranhão (MARANHÃO, 2017).

\section{REFERÊNCIAS}

ABDO, Helena Najjar. A garantia da publicidade do processo e a divulgação de atos processuais pela mídia: limites e precauções atinentes ao processo civil. In: XVII Encontro Preparatório para o Congresso Nacional do CONPEDI, 2008, Salvador. Anais. Disponível em:

$<$ http://www.conpedi.org.br/manaus/arquivos/anais/salvador/helena_na jjar_abdo.pdf $>$. Acesso em 11 jun. 2017. 


\section{REVISTA ESTUDOS INSTITUCIONAIS}

ALEXY, Robert. Teoria da argumentação jurídica. São Paulo: Landy, 2001.

ALEXY, Robert. Teoria dos direitos fundamentais. São Paulo:

Malheiros Editores, 2017.

ALMADA, Roberto José Ferreira de. A garantia da Publicidade no

Processo Civil. Dissertação de mestrado. Faculdade de Direito de

Vitória, Vitória, 2004. Disponível em:

$<$ http://www.dominiopublico.gov.br/download/teste/arqs/cp076445.pdf

>. Acesso em 26 jun. 2017.

BARROSO, Luís Roberto. Interpretação e aplicação da constituição: fundamentos de uma dogmática constitucional transformadora. São Paulo: Saraiva, 1999.

BECCARIA, Cesare. Dos delitos e das penas. São Paulo: Marin Claret, 2011.

BOBBIO. Norberto. O futuro da democracia. Rio de Janeiro: Paz e terra, 1986.

BRASIL. Constituição (1988). Constituição da República Federativa do Brasil. Brasília. Disponível em $<$ http://www.planalto.gov.br/ccivil_03/constituicao/constituicao.htm>. Acesso em 01 jun. 2017.

BRASIL. Lei Complementar no 64, de 18 de maio de 1990. Estabelece, de acordo com o art. 14, § $9^{\circ}$ da Constituição Federal, casos de inelegibilidade, prazos de cessação, e determina outras providências. Disponível em <http://www.planalto.gov.br/ccivil_03/leis/lcp/lcp64.htm>. Acesso em 30 jul. 2017. 


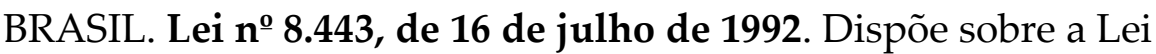
Orgânica do Tribunal de Contas da União e dá outras providências. Disponível em <http://www.planalto.gov.br/ccivil_03/leis/L8443.htm>. Acesso em 1 jun. 2017.

BRASIL. Lei no 8.906, de 4 de julho de 1994. Dispõe sobre o Estatuto da Advocacia e a Ordem dos Advogados do Brasil (OAB). Disponível em: $<$ http://www.planalto.gov.br/ccivil_03/leis/L8906.htm>. Acesso em 1 jun. 2017.

BRASIL. Supremo Tribunal Federal. Recurso Extraordinário no 190.985. Relator: Ministro Néri da Silveira. Brasília, 14 de fev. 1996. Disponível em: < http://www.stf.jus.br/portal/constituicao/artigoBd.asp?item=860 $>$. Acesso em 19 jul. 2018.

BRASIL. Lei no 9.784, de 29 de janeiro de 1999. Regula o processo administrativo no âmbito da Administração Pública Federal. Disponível em: < http://www.planalto.gov.br/ccivil_03/leis/L9784.htm>. Acesso em 24 jul. 2017.

BRASIL. Tribunal de Contas da União. Resolução TCU no 155, de 4 de dezembro de 2002. Estabelece o Regimento Interno do Tribunal de Contas da União. Boletim do Tribunal de Contas da União Especial v. 1, n. 1. Brasília: TCU, 2015.

BRASIL. Supremo Tribunal Federal. Mandado de Segurança no 24.4054/DF. Relator: Min. Carlos Velloso. Brasília, 03 de dez. 2003. Disponível em:

$<$ http://redir.stf.jus.br/paginadorpub/paginador.jsp?docTP=AC\&docID= 86127>. Acesso em 30 jun. 2017.

BRASIL. Congresso Nacional. Emenda Constitucional no ${ }^{0}$, de 30 de dezembro de 2004. Disponível em: 


\section{REVISTA ESTUDOS INSTITUCIONAIS}

$<$ http://www.planalto.gov.br/ccivil_03/constituicao/emendas/emc/emc45 .htm>. Acesso em 30 jul. 2017.

BRASIL. Senado Federal. Resolução no 16, de 14 de março de 2006. Disponível em:

$<$ http://legis.senado.gov.br/legislacao/ListaPublicacoes.action?id=25387> . Acesso em 15 jun. 2017.

BRASIL. Tribunal de Contas da União. Resolução no 191, de 21 de junho de 2006. Estabelece procedimentos para recebimento, autuação e tramitação de processos e documentos relativos à área de controle externo. Disponível em:

$<$ http://portal.tcu.gov.br/lumis/portal/file/fileDownload.jsp?fileId=8A81 82A14D056C05014D061158CF1BCB>. Acesso em 10 jun. 2017.

BRASIL. Tribunal de Contas da União. Portaria-ADPLAN no 1, de 25 de janeiro de 2010. Aprova o documento Orientações para Auditorias de Conformidade. Disponível em:

$<$ https://portal.tcu.gov.br/lumis/portal/file/fileDownload.jsp?fileId...>. Acesso em 18 jul. 2018.

BRASIL. Tribunal de Contas da União. Acórdão no 2.412 - Plenário. Relator: Ministro-Substituto. Weder de Oliveira. Brasília, DF, 15 mar. 2010. Disponível em:

$<$ https://contas.tcu.gov.br/pesquisaJurisprudencia/\#/detalhamento/11/24 12\%252F2010/\%2520/DTRELEVANCIA \%2520desc\%252C\%2520NUMA CORDAOINT\%2520desc/false/1/false>. Acesso em 30 jul. 2017.

BRASIL. Lei no $\mathbf{1 2 . 5 2 7}$, de 18 de novembro de 2011. Regula o acesso a informações. Disponível em:

$<$ http://www.planalto.gov.br/ccivil_03/_ato2011-

2014/2011/lei/112527.htm>. Acesso em 01 jun. 2017. 


\section{A INCONSTITUCIONALIDADE DA PUBLICIDADE RESTRITA DOS PROCESSOS NO TRIBUNAL DE CONTAS DA UNIÃO}

BRASIL, Tribunal de Contas da União. Resolução no 249, de 02 de maio de 2012. Dispõe sobre o acesso à informação e a aplicação da Lei 12.527, de 18 de novembro de 2011, no âmbito do Tribunal de Contas da União. Disponível em:

$<$ https://www.google.com.br/url?sa=t\&rct=j\&q=\&esrc=s\&source=web\&c $\mathrm{d}=1 \& \mathrm{cad}=$ rja\&uact $=8 \&$ ved $=0$ ahUKEwiu 4 LKFtOnXAhVKH5AKHacUAB EQFggnMAA\&url=http\%3A\%2F\%2Fwww.tcu.gov.br\%2FConsultas\%2F Juris\%2FDocs\%2Fjudoc\%2FResol\%2F20120509\%2FRES2012249.doc\&usg=AOvVaw3DOnfVnK2ZJRkz4mHZ88Ht>. Acesso em 01 dez. 2017.

BRASIL. Supremo Tribunal Federal. Mandado de Segurança $\mathbf{n}^{\mathbf{0}}$ 26.969/DF. Relator: min. Luiz Fux. Brasília, 18 jun. 2014. Disponível em: $<$ http://portal.stf.jus.br/processos/detalhe.asp?incidente=2569554>. Acesso em 15 jul. 2018.

BRASIL. Controladoria Geral da União. Manual da lei de acesso à informação para estados e municípios. CGU, 2013. Disponível em: $<$ http://www.cgu.gov.br/Publicacoes/transparencia-publica/brasiltransparente/arquivos/manual_lai_estadosmunicipios.pdf $>$. Acesso em 31 jul. 2017.

BRASIL. Lei no 13.105, de 16 de março de 2015. Código de processo civil. Disponível em < http://www.planalto.gov.br/ccivil_03/_ato20152018/2015/lei/113105.htm>. Acesso em 30 jul. 2017.

BRASIL. Supremo Tribunal Federal. Súmula vinculante no 3 . Versão resumida. Brasília, 2016.

BRASIL. Supremo Tribunal Federal. Súmula vinculante no ${ }^{14}$. Versão resumida. Brasília, 2016. 


\section{REVISTA ESTUDOS INSTITUCIONAIS}

BRASIL. Superior Tribunal de Justiça. Recurso Especial no $\mathbf{1 . 4 8 0 . 3 5 0 ~ - ~}$ RS. Relator: Ministro Benedito Gonçalves. Brasília, 05 de ab. 2016. Disponível em <https://stj.jusbrasil.com.br/jurisprudencia/339731709/recurso-especialresp-1480350-rs-2014-0142962-8/inteiro-teor-339731724?ref=juris-tabs> Acesso em 19 jul. 2018.

BRASIL. Tribunal de Contas da União. Acórdão no 5.928 - 2ª̂ Câmara. Relator: Min. Vital do Rêgo. Brasília, DF, 17 jun. 2016. Disponível em: $<$ https://contas.tcu.gov.br/juris/SvlHighLight?key=41434f5244414f2d434f 4d504c45544f2d31373439383138\&sort=RELEVANCIA\&ordem=DESC\&b ases $=\mathrm{ACORDAO}-$

COMPLETO;\&highlight=\&posicaoDocumento=0\&numDocumento=1\&t otalDocumentos=1> Acesso em 30 jul. 2017.

BRASIL. Tribunal de Contas da União. Acórdão no 232 - 1ª Câmara.

Relator: Min. Bruno Dantas. Brasília, DF, 24 jan. 2017. Disponível em: < https://contas.tcu.gov.br/pesquisaJurisprudencia/\#/detalhamento/11/232 \%252F2017/\%2520/DTRELEVANCIA\%2520desc\%252C\%2520NUMACO RDAOINT\%2520desc/false/2/false> Acesso em 30 jul. 2017.

BRASIL. Tribunal de Contas da União. Acórdão no 922 - Plenário.

Relator: Min. Aroldo Cedraz. Brasília, DF, 10 mai. 2017. Disponível em: $<$ https://contas.tcu.gov.br/pesquisaJurisprudencia/\#/detalhamento/11/92 2\%252F2017/\%2520/DTRELEVANCIA \%2520desc\%252C\%2520NUMAC ORDAOINT\%2520desc/false/1/false> Acesso em 30 jul. 2017.

BRASIL. Tribunal de Contas da União. Acórdão no 1.081 - Plenário. Relator: Min. Weder de Oliveira Brasília, DF, 24 mai. 2017. Disponível em:

$<$ https://contas.tcu.gov.br/pesquisaJurisprudencia/\#/detalhamento/11/ac \%25C3\%25B3rd \%25C3\%25A3o\%2520n\%25C2\%25BA \%25201.081\%252F2 017\%2520/\%2520/DTRELEVANCIA\%2520desc\%252C\%2520NUMACOR DAOINT\%2520desc/false/1/false> Acesso em 30 jul. 2017. 
BRASIL. Tribunal de Contas da União. Acórdão n⿳0 6104 - 2ª̂amara. Relator: Min. Vital do Rêgo. Brasília, Brasília, 04 jul. 2017. Disponível em:

$<$ https://contas.tcu.gov.br/pesquisaJurisprudencia/\#/detalhamento/11/61 04\%252F2017/\%2520/DTRELEVANCIA\%2520desc\%252C\%2520NUMA CORDAOINT\%2520desc/false/2/false> Acesso em 30 jul. 2017.

BRASIL. Tribunal de Contas da União. Acórdão no 11.224/2017-1

Câmara. Relator: Min. Walton Alencar Rodrigues, Brasília, 05 dez. 201. Disponível em:

$<$ https://contas.tcu.gov.br/pesquisaJurisprudencia/\#/detalhamento/11/11. 224\%252F2017/\%2520/DTRELEVANCIA\%2520desc\%252C\%2520NUMA CORDAOINT\%2520desc/false/1/false>. Acesso em 16 jul. 2018.

BUSTAMENTE, Thomas. Princípios, regras e conflitos normativos: uma nota sobre a superabilidade das regras jurídicas e as decisões contra legem. Revista Direito, sociedade e Estado, n. 37, 2010. Disponível em: $<$ http://direitoestadosociedade.jur.pucrio.br/media/Artigo7\%20Thomas.pdf>. Acesso em 09 jul. 2018.

COMISSÃO INTERAMERICANA DE DIREITOS HUMANOS. Declaração Interamericana de Princípios de Liberdade de Expressão (2000). Disponível em:

$<$ https://www.cidh.oas.org/basicos/portugues/s.Convencao.Libertade.de .Expressao.htm> Acesso em 31 jul. 2017.

DINAMARCO, Cândido Rangel. A instrumentalidade do processo. São Paulo: Malheiros Editores, 2001.

GUALAZZI, Eduardo Lobo Botelho. Regime jurídico dos Tribunais de Contas. São Paulo: Editora Revista dos Tribunais, 1992. 


\section{REVISTA ESTUDOS INSTITUCIONAIS}

INTOSAI. Organização Internacional de Entidades Fiscalizadoras Superiores. Princípios de transparência e accountability. 2010. Disponível em <http://portal.tcu.gov.br/lumis/portal/file/fileDownload.jsp?fileId=8A81 82A2561DF3F501562329409F78D5>. Acesso em 27 jun. 2017.

LEFEBVRE, Henri. Posição: contra os tecnocratas. São Paulo: Nova Crítica, 1969.

LIMA, Luiz Henrique. Controle externo. Rio de Janeiro: Forense; São Paulo: MÉTODO, 2015. E-Book.

LISBOA, Marcelo Jucá. Metodologia jurídica e sua relação com o conceito, interpretação e aplicação do direito: uma visão panorâmica. In Revista Jurídica Luso-Brasileira, n. 2, 2016. Disponível em: $<$ http://www.cidp.pt/publicacoes/revistas/rjlb/2016/2/2016_02_0849_0909 .pdf >. Acesso em 18 jul. 2018. p. 849-910.

MARANHÃO (Estado). Tribunal de Contas do Estado do Maranhão. Instrução Normativa TCE/MA no 49, de 30 de agosto de 2017. Altera dispositivos da Instrução Normativa TCE/MA nº 028, de 29 de agosto de 2012 e dá outras providências. Disponível em < http://site.tce.ma.gov.br/index.php/intranet/2-uncategorised/87instrucoes-normativas> Acesso em 01 dez. 2017.

OLIVEIRA, Odilon Cavallari de. A instrução processual no Tribunal de Contas da União em face de um processo célere e consistente juridicamente: os desafios dos novos tempos. Revista do Tribunal de Contas da União. Ano 38. n.108. Brasília: TCU, 2007. Disponível em $<$ https://revista.tcu.gov.br/ojs/index.php/RTCU/article/view/470/521>. Acesso em 26 jul. 2017.

ORGANIZAÇÃO DAS NAÇÕES UNIDAS (ONU). Declaração dos direitos humanos. ONU, 1948. Disponível em: 
$<$ https://www.ohchr.org/EN/UDHR/Pages/Language.aspx?LangID=por > . Acesso em 31 jul. 2017.

ORGANIZAÇÃO DAS NAÇÕES UNIDAS (ONU). Pacto Internacional dos Direitos Civis e Políticos (1966). Disponível em < http://www.planalto.gov.br/ccivil_03/decreto/1990-1994/d0592.htm>. Acesso em 31 jul. 2017.

ORGANIZAÇÃO DAS NAÇÕES UNIDAS (ONU). Convenção das Nações Unidas contra a Corrupção (2003). Disponível em < https://www.unodc.org/lpo-brazil/pt/corrupcao/convencao.html>. Acesso em 31 jul. 2017.

SANTOS, Nelton Agnaldo Moraes dos. Princípio da publicidade. In: OLIVEIRA NETO, Olavo de; LOPES, Maria Elizabeth de Castro. Princípios processuais civis na constituição. Rio de Janeiro: Elsevier, 2008, p.173-192.

TEIXEIRA, Elizabeth. As três metodologias: acadêmica, da ciência e da pesquisa. Rio de Janeiro: Editora Vozes, 2005.

TRIBUNAL EUROPEU DOS DIREITOS DO HOMEM. Convenção europeia dos direitos do homem. Disponível em:

$<$ http://www.echr.coe.int/Documents/Convention_POR.pdf > Acesso em 03. Dez. 2017.

ZYMLER, Benjamin. Processo administrativo no Tribunal de Contas da União. Brasil. Tribunal de Contas da União. Prêmio Serzedello Corrêa 1996: Monografias Vencedoras. Brasília: Instituto Serzedello Corrêa, Serviço de Editoração e Publicações, 1997. p. 139-217.

RECEBIDO EM: 15/02/2018. ACEITO EM: 24/08/2018. 